\title{
Geochemical diagnostics of metasedimentary dark enclaves: a case study from the Peninsular Ranges Batholith, southern California
}

\author{
Kelley Z. Liao ${ }^{\mathrm{a} *}$, Douglas M. Morton ${ }^{\mathrm{b}}$ and Cin-Ty A. Lee ${ }^{\mathrm{a} *}$ \\ ${ }^{a}$ Department of Earth Science, Rice University, MS-126, Houston, TX, USA; ${ }^{b}$ Department of Earth Science, University of California, \\ Riverside, $C A, U S A$
}

(Accepted 25 November 2012)

\begin{abstract}
Dark enclaves rich in amphibole and biotite are ubiquitous in granitoid rocks and typically represent fragments of mafic magmas, cumulates, restites, or country rocks. To develop criteria for identifying dark enclaves of non-magmatic origin, we investigated dark enclaves from a complete spectrum of light (carbonate- or feldspar-rich) to dark (amphibole-rich, biotite-rich, or composite) enclaves, reflecting progressive thermal and chemical equilibration with the host tonalite, the Domenigoni Valley pluton in the Peninsular Ranges Batholith, California. Metasedimentary dark enclaves have geochemical characteristics that overlap those of literature-compiled igneous dark enclaves. When compared with modelled igneous differentiation paths, metasedimentary enclaves can have anomalous $\mathrm{CaO}$ and $\mathrm{K}_{2} \mathrm{O}$ contents for a given $\mathrm{SiO}_{2}$, but other major-element systematics may not deviate noticeably from igneous differentiation trends. In addition, the fact that literature-compiled mafic enclaves trend towards high $\mathrm{K}_{2} \mathrm{O}+\mathrm{CaO}$ suggests that not all mafic enclaves are of igneous origin. In this work, we provide criteria for identifying enclaves of possible metasedimentary origin.
\end{abstract}

Keywords: enclaves; metasedimentary; country-rock metamorphism; protolith; assimilation; geochemical equilibration

\section{Introduction}

Dark inclusions rich in mafic minerals are ubiquitous in granitoid plutons (Didier 1973; Eichelberger 1975; Frost and Mahood 1987; Vernon 1990; Poli and Tommasini 1991; Blundy and Sparks 1992; Tobisch et al. 1997; Wiebe et al. 1997; Barbarin 2004). Often referred to as 'mafic enclaves', these inclusions have high abundances of minerals such as biotite and amphibole. Dark enclaves are generally thought to represent fragments of entrained cumulates, restites, or mafic magmas and hence interpreted to reflect igneous origins (White and Chappell 1977; Bacon 1986; Dodge and Kistler 1990; Blundy and Sparks 1992; Chappell 1995). However, in some instances, dark enclaves may reflect fragments of sedimentary and metamorphic country rocks that have been entrained in a pluton body (Phillips et al. 1981; Price 1983; Chen et al. 1989; Maas et al. 1997). One possible mechanism for this is the stoping of pluton bodies through country rocks (Glazner et al. 2004). Following entrainment, these country-rock fragments are metamorphosed. Specifically, country rocks rich enough in $\mathrm{Ca}$ or $\mathrm{K}$ and $\mathrm{Al}$ can be thermally metamorphosed into amphibole-rich and biotite-rich rocks, respectively. As a result, the dark macroscopic appearance of these non-magmatic enclaves can resemble igneous enclaves (Figure 1). Although it is unclear whether a metasedimentary origin for mafic enclaves is significant compared to igneous origins, erroneously attributing metasedimentary dark enclaves to igneous protoliths will lead to misunderstanding of how magmas are generated, emplaced, and differentiated. For example, assimilation of sedimentary country rocks may release more volatiles, such as $\mathrm{CO}_{2}, \mathrm{H}_{2} \mathrm{O}$ (Dyer et al. 2011; Lee et al. 2012), and various $\mathrm{S}$ species, than intrusion of mafic magmas into felsic magmas.

Thus, there is a need to develop criteria for identifying the protoliths of dark enclaves. Towards these ends, we examine a suite of dark enclaves from a tonalitic pluton in the Cretaceous northern Peninsular Ranges Batholith (PRB) in southern California (Figure 2). These enclaves have unequivocal metasedimentary protoliths and are present in various stages of thermal and chemical equilibration with the host magma, resulting in the generation of dark enclaves that appear superficially like typical igneous mafic enclaves. This case study provides an opportunity to develop some criteria for identifying non-magmatic dark enclaves.

\section{Geologic background}

The Cretaceous PRB extends from southern California through Baja California (Figure 3). Three zones within

*Corresponding authors. Email: kelleyzliao@gmail.com (Kelley Liao) or ctlee@rice.edu (Cin-Ty Lee) 
(A)

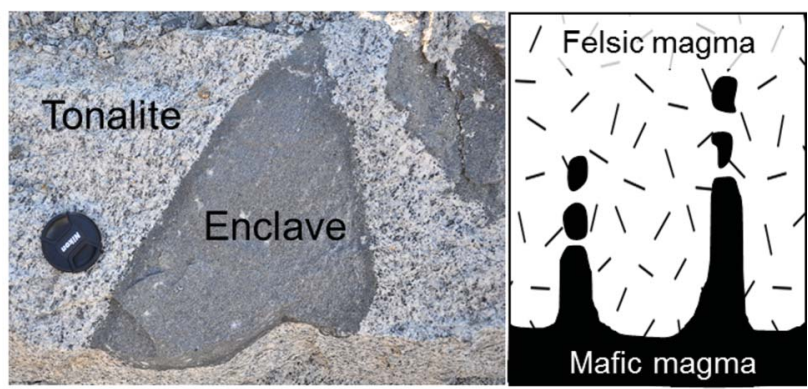

(B)

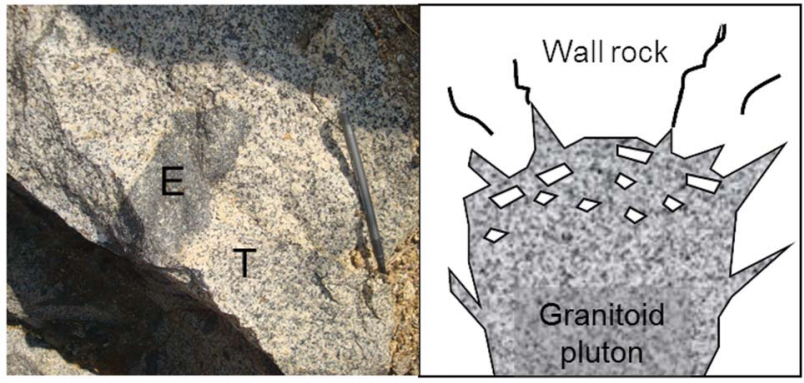

Figure 1. Schematic cartoon for two different mechanisms of enclave formation. (A) Dark enclaves from the Sierra Nevada Batholith are igneous in origin and likely formed by the fragmentation of mafic magmas intruded into felsic magma. (B) A dark metasedimentary enclave from the PRB is hosted by tonalite and formed by the entrainment of wall rock fragments in a stoping pluton body. Both enclaves are angular and rich in mafic minerals.

the batholith can be distinguished based on the composition of their pre-batholithic rocks (Gastil 1975; Gromet and Silver 1987; Todd et al. 1988; Lee et al. 2007). Pre-batholithic rocks in the western region consist of Late Jurassic and Early Cretaceous subaerial and submarine volcanic and volcaniclastic rocks, thought to be an accreted island arc. Pre-batholithic rocks in the central portion consist of Triassic to Cretaceous continentally derived flysch sediments, and in the eastern zone, they consist of passive margin clastic sediments (Wetmore et al. 2003). The PRB was emplaced through these rocks in the middle to Late Cretaceous (140 and $80 \mathrm{Ma})$ in an ocean-continent subduction zone setting (Kistler et al. 2003).

Our study region is a pluton-wallrock contact zone in the Domenigoni Valley pluton, located in the northern PRB near Sun City in Riverside County, California (Figure 3) (Morton 1999). The pluton is composed of biotite and hornblende tonalite, and it intruded Triassic phyllites, greywackes, dirty quartzites, carbonate-bearing quartzites, and interbedded phyllites with quartzites. Assimilation of these metasediments is evident in roadcuts on the western margin of the pluton. Fragments of metasediments as well as dark enclaves are exposed in roadcuts of the Domenigoni Valley pluton along the 215 Freeway in Sun City $\left(33^{\circ} 42^{\prime}\right.$ $\left.8.65^{\prime \prime} \mathrm{N}, 117^{\circ} 10^{\prime} 54.95^{\prime \prime} \mathrm{W}\right)$.

\section{Methods}

Whole-rock analysis of major and trace element abundances for the various enclave types was carried out by ICP-AES-MS and XRF at USGS laboratories. All analyses of individual mineral phases were completed at Rice University using laser ablation ICP-MS on a Thermo Finnigan Element 2 equipped with a $213 \mathrm{~nm}$ New Wave laser ablation system. Standard thick sections $(200 \mu \mathrm{m})$ were analysed with the laser ICP-MS. External standards used during LA-ICP-MS analysis included $\mathrm{BHVO} 2 \mathrm{~g}$, BCR2g, BIR1, and NIST612. Laser ablation was conducted with a fluence of $19 \mathrm{~J} / \mathrm{cm}^{2}$, frequency of $10 \mathrm{~Hz}$, and a spot size of $55 \mu \mathrm{m}$. Under these conditions, instrument sensitivity was $120,000 \mathrm{cps}$ on $15 \mathrm{ppm} \mathrm{La}$ in low mass resolution $(m / \Delta m \sim 300)$. Raw data from LA-ICP-MS were reduced using a program that removes background signal intensities in each analysis. Then, time-resolved signals for various elements analysed were selected with the criteria they are parallel, in order to avoid interference from contaminant phases. The remaining signal intensities were normalized to an internal standard. ${ }^{30} \mathrm{Si}$ was used as the internal standard for all mineral phases measured in medium mass resolution, while ${ }^{25} \mathrm{Mg}$ was used for biotite and hornblende analysis in low resolution. Normalizing to an internal standard corrects for the fact that ablating samples under varying conditions will affect the absolute signal intensities.

\section{Results}

\subsection{Petrography}

\subsubsection{Tonalite}

The host tonalite is composed of approximately $10 \%$ amphibole, $15 \%$ biotite, $30 \%$ quartz, and $40 \%$ plagioclase. Accessory phases include zircon, Fe-Ti oxides, and titanite. Texturally, the tonalite is medium-grained to coarsegrained with subhedral to euhedral plagioclase grains surrounded by mostly anhedral quartz, biotite, and amphibole. Plagioclases not only show polysynthetic albite twinning but also show crystallographic radial and sector zoning, the latter being typical of magmatic feldspars. Many of the plagioclase cores also have a corroded appearance due to the presence of many micron-scale inclusions of fluids, biotite, and amphibole, typical of magmatic crystallization textures (Barbarin 1990; Hibbard 1995). Some of the inclusions are carbonates. Quartz displays undulose extinction. Amphibole and biotite are anhedral and often occur as intergrown aggregates. Biotite can also be found as aggregates surrounding large plagioclase crystals. Accessory titanite typically occurs as thin rims $(<0.05 \mu \mathrm{m})$ around Fe-Ti oxide grains.

\subsubsection{Enclaves}

Enclaves range from decimetres to metres in size and can be classified as dark enclaves abundant in mafic mineral 


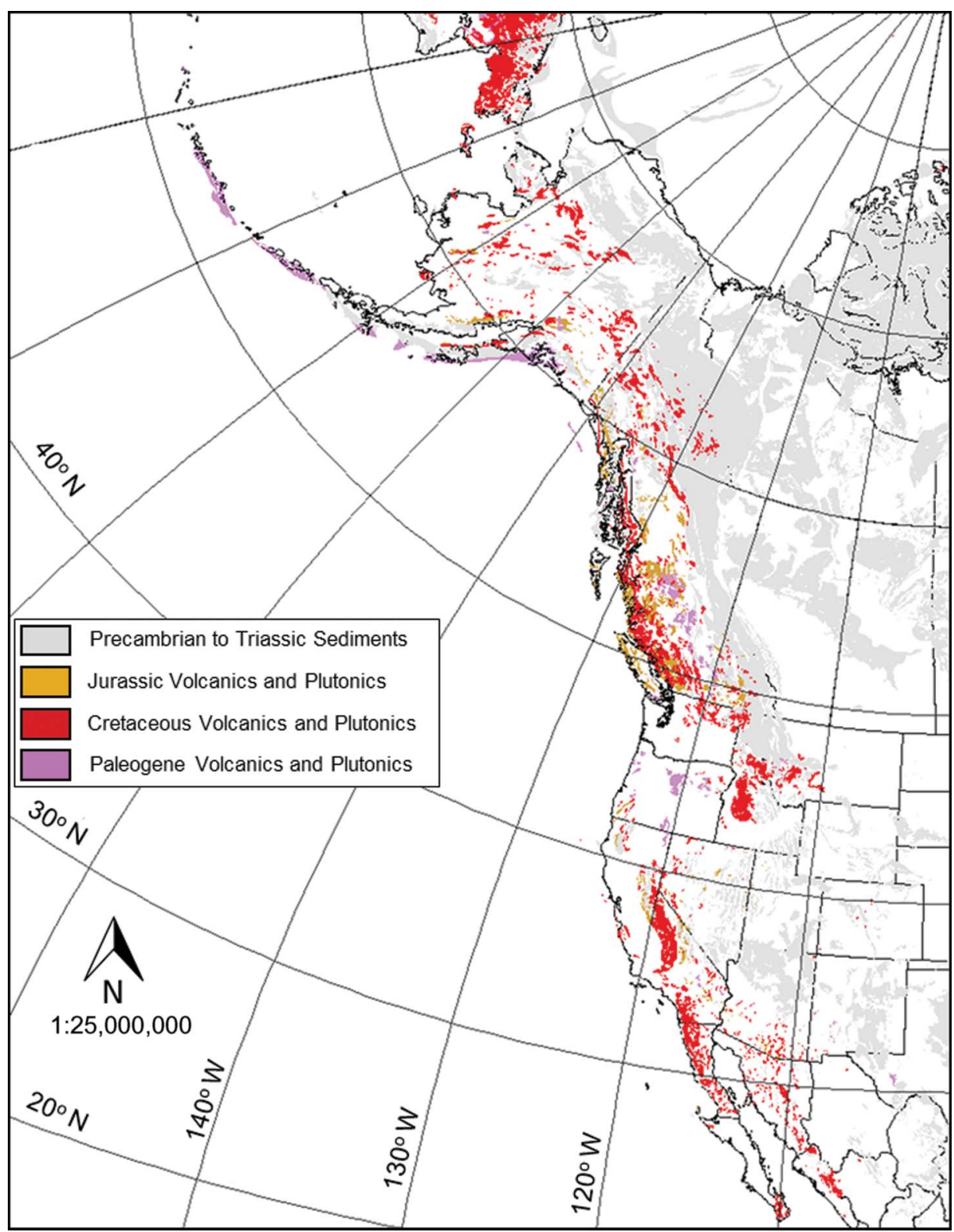

Figure 2. Map of Cretaceous plutons along the western margin of North America (map is based on data from Garrity and Soller 2009).

phases and lighter-coloured enclaves abundant in quartz and variable amounts of carbonate. Both enclave types are fine-grained. Grains are almost entirely anhedral, with grain boundaries between quartz and feldspars showing well-equilibrated textures, e.g. $120^{\circ}$ triple junctions.

4.1.2.1. Dark enclaves. We categorize the dark enclaves based on their dominant mafic mineral phase (Table 1 and Figure 4). The amphibole-rich group is composed of quartz $(\sim 60 \%)$, amphibole $(\sim 30 \%)$, and minor plagioclase. These enclaves exhibit subtle foliation defined by $1-5 \mathrm{~mm}$-thick amphibole-rich bands. Clinopyroxene is present in trace amounts and often appears to be replaced by amphibole.
At the contact between the amphibole-rich enclave and the host tonalite, there is a $<1 \mathrm{~mm}$ biotite-rich rim, reflecting $\mathrm{K}$ diffusion from tonalite to enclave (cf. Johnston and Wyllie 1988).

The biotite-rich group is dominated by quartz $(\sim 50 \%)$ and biotite $(\sim 40 \%)$ with small amounts of alkali feldspar. Some of the biotite-rich enclaves are finely foliated, reflecting relict metamorphic foliation. Fe-Ti oxide minerals are a common accessory phase and often found in association with biotite grains.

Composite enclaves, containing both of the above lithologies in the form of alternating bands are also present and may indicate macro-scale compositional heterogeneities in the protolith. 


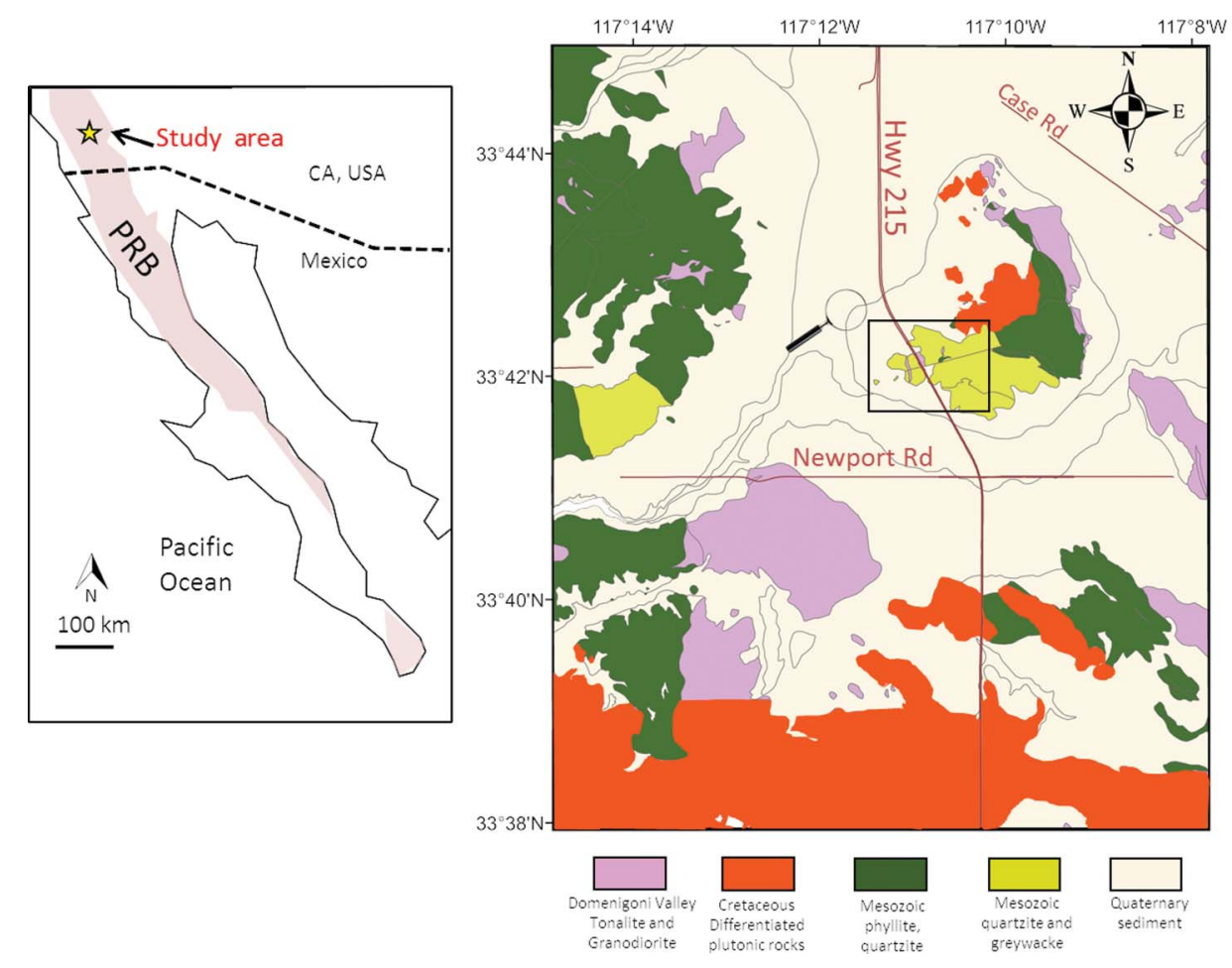

Figure 3. Geologic map of the Domenigoni Valley pluton. This region is located in the northern PRB. The pluton intrudes Mesozoic sediments, notably quartzite interbedded with carbonate-bearing layers, greywackes, and phyllites (map is based on data in Morton 1999).

Table 1. Dark enclave modal proportion and major-element composition.

\begin{tabular}{|c|c|c|c|c|c|c|}
\hline Enclave type & Biotite-rich & & Amphibolite & & Dark composite & \\
\hline Mineralogy & Mode (\%) & & & & & \\
\hline Quartz (Qz) & 50 & & 60 & & $40-45$ & \\
\hline Plagioclase (PI) & & & 5 & & $0-5$ & \\
\hline Alkali Feldspar (Kf) & 5 & & & & 5 & \\
\hline Biotitle (Bt) & 40 & & $<5$ & & $30-40$ & \\
\hline Amphibole (Am) & $<5$ & & 30 & & $5-30$ & \\
\hline Fe-oxides $(\mathrm{Ox})$ & $<5$ & & $<5$ & & $<5$ & \\
\hline Diopside (Di) & & & $<5$ & & $<5$ & \\
\hline \multicolumn{7}{|l|}{ Wollastonite (Wo) } \\
\hline \multicolumn{7}{|l|}{ Calcite (Cc) } \\
\hline \multicolumn{7}{|l|}{ Clinozoisite (Cz) } \\
\hline & & $1 \mathrm{SD}$ & & & & \\
\hline & & $n=5$ & & $n=3$ & & $n=6$ \\
\hline $\mathrm{SiO}_{2}($ wt.\%) & 62.5 & 1.93 & 65.2 & 11.45 & 65.5 & 9.31 \\
\hline $\mathrm{TiO}_{2}$ & 0.7 & 0.08 & 0.71 & 0.29 & 0.63 & 0.29 \\
\hline $\mathrm{Al}_{2} \mathrm{O}_{3}$ & 16.4 & 0.86 & 15.11 & 7.83 & 13.79 & 6.94 \\
\hline $\mathrm{Cr}_{2} \mathrm{O}_{3}$ & 0.01 & 0.01 & 0.02 & 0.01 & 0.02 & 0.01 \\
\hline $\mathrm{FeO}_{\mathrm{T}}$ & 6.44 & 1.36 & 5.63 & 1.23 & 5.31 & 0.75 \\
\hline $\mathrm{MgO}$ & 0.09 & 0.03 & 0.09 & 0.02 & 0.1 & 0.04 \\
\hline $\mathrm{MnO}$ & 1.69 & 0.33 & 1.68 & 0.2 & 1.82 & 0.2 \\
\hline $\mathrm{CaO}$ & 3.21 & 0.95 & 5.91 & 1.67 & 6.84 & 4.3 \\
\hline $\mathrm{Na}_{2} \mathrm{O}$ & 3.14 & 0.19 & 3.19 & 1.82 & 2.62 & 1.58 \\
\hline $\mathrm{K}_{2} \mathrm{O}$ & 4.84 & 2.2 & 1.88 & 1.48 & 2.57 & 1.96 \\
\hline $\mathrm{P}_{2} \mathrm{O}_{5}$ & 0.17 & 0.02 & 0.18 & 0.01 & 0.16 & 0.02 \\
\hline Total & 99.15 & & 99.63 & & 99.36 & \\
\hline
\end{tabular}




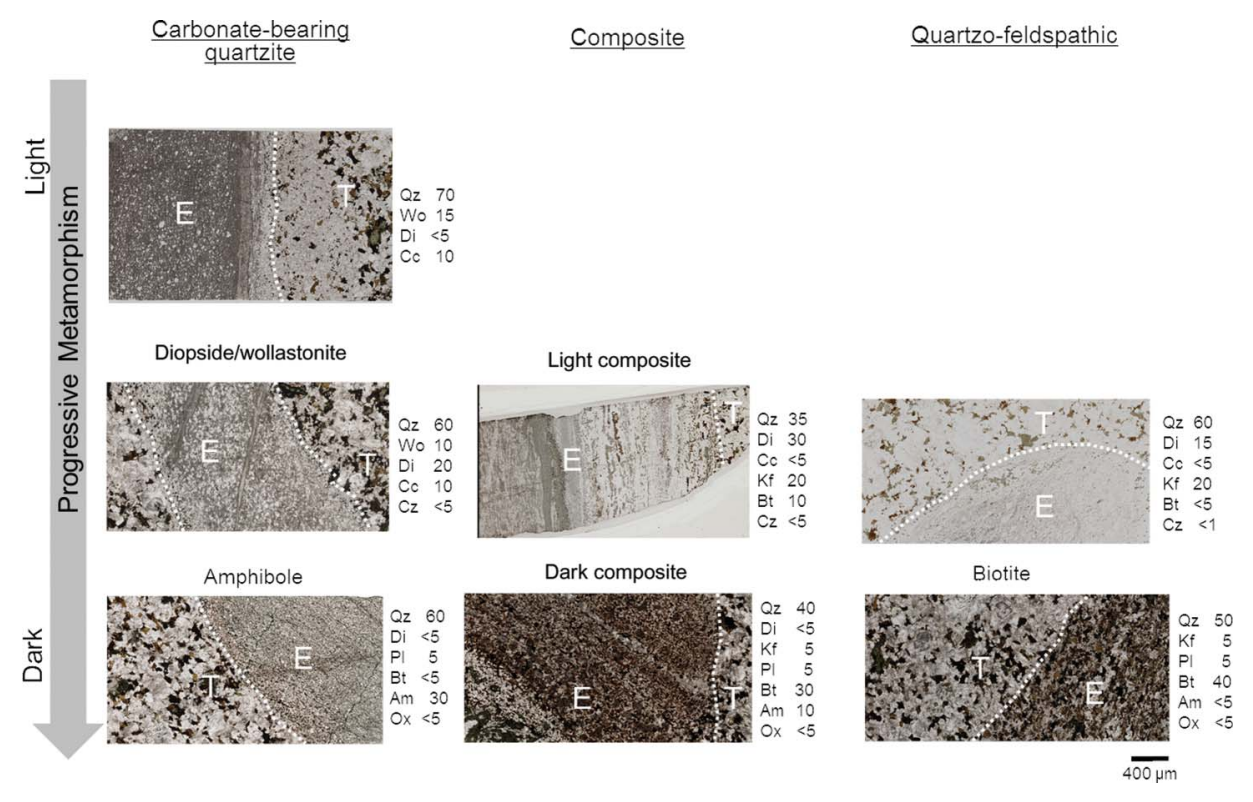

Figure 4. Thin sections of enclaves (E) in contact with the host tonalite (T), arranged from least to most metamorphosed. On the left column, metamorphism of carbonate-bearing quartzite progresses to an amphibolite dark enclave. On the right column, quartzo-feldspathic enclaves progress towards biotite-rich enclaves. The middle column shows that light composite enclaves contain feldspar- and carbonatebearing layers, while dark composite enclaves preserve layers that are either biotite or amphibole rich. Mineral assemblages and their modal proportion are given for each enclave sample. Qz $=$ Quartz, $\mathrm{Cc}=$ Calcite, $\mathrm{Do}=$ Dolomite, Wo $=$ Wollastonite, $\mathrm{Di}=\mathrm{Diopside}$, $\mathrm{Am}=$ Amphibole, $\mathrm{Bt}=$ Biotite, $\mathrm{Pl}=$ Plagioclase, $\mathrm{Kf}=\mathrm{K}$-feldspar, $\mathrm{Ox}=\mathrm{Fe}$-oxides .

4.1.2.2. Light enclaves. Light enclaves are dominantly composed of quartz, but can be classified into two groups. The first group is composed of carbonate-bearing quartzites, containing $60 \%$ to $80 \%$ quartz and variable amounts of wollastonite (0-30\%), diopside (0-20\%), and carbonate (5-15\%) (Table 2). These enclaves are finegrained and consist of anhedral grains showing wellequilibrated granular textures manifested as $120^{\circ}$ triple junctions. Quartz grains range from 1 to $10 \mu \mathrm{m}$. Pyroxenes and carbonates are much finer grained, with individual grains no larger than $2 \mu \mathrm{m}$. Wollastonite and diopside often appear as bands cutting through the enclave (Figure 4). Clinozoisite is present in trace amounts and is often found near pyroxenes. A thin rind of amphibole often rims the carbonate-bearing quartzite enclaves, indicating reaction between the pyroxenes and the tonalite.

The second group of light enclaves are enclaves with quartzo-feldspathic protoliths. These contain quartz (60\%), alkali feldspar $(>20 \%)$, diopside $(15 \%)$, biotite $(<5 \%)$, and minor carbonate. These enclaves are more fine-grained than carbonate-bearing enclaves and show foliated texture, particularly when biotite is present.

The third category is composed of light composite enclaves, which are dominated by quartz (35\%), diopside (30\%), alkali feldspar (20\%), and minor carbonate and clinozoisite. Layers of varying mineralogy are visible in thin section. In several samples, a biotite rich layer occurs close to the contact between the enclave and tonalite.
Amphibole-rich layers are also apparent, but they are located further from the contact. Except for areas that are biotite rich, light composite enclaves are fine-grained.

\subsection{Geochemistry}

\subsubsection{Whole-rock major elements}

The host tonalite is relatively homogeneous, at least on outcrop scale $(20-30 \mathrm{~m})$, and is characterized by $64-66 \mathrm{wt} . \%$ $\mathrm{SiO}_{2}, 1.5-2$ wt.\% MgO, 3-5 wt.\% CaO, 6 wt.\% $\mathrm{FeO}_{\mathrm{T}}$, 16 wt. $\% \mathrm{Al}_{2} \mathrm{O}_{3}$, and $\sim 5$ wt. $\%$ total alkalis (Figure 5).

By contrast, the enclaves show considerable majorelement heterogeneity. For example, $\mathrm{SiO}_{2}$ contents range from 50 to $85 \mathrm{wt}$ \%. For most major elements, there is considerable overlap between the two colour types of enclaves, although dark enclaves tend to be richer in $\mathrm{Fe}, \mathrm{Mg}$, and $\mathrm{Al}$ and poorer in Si than light enclaves (Figure 5). Subtle but important differences between enclave subclasses are evident. Dark enclaves rich in biotite are very similar in composition to the host tonalite for most major elements, e.g. $\mathrm{MgO}, \mathrm{FeO}_{\mathrm{T}}, \mathrm{SiO}_{2}, \mathrm{Na}_{2} \mathrm{O}$, and $\mathrm{Al}_{2} \mathrm{O}_{3} \cdot \mathrm{K}_{2} \mathrm{O}$ contents in three biotite-rich dark enclaves are much higher than in tonalite, but it is noteworthy that two biotiterich samples have $\mathrm{K}_{2} \mathrm{O}$ contents indistinguishable from tonalite. The amphibole-rich dark enclaves have similar $\mathrm{MgO}$ and $\mathrm{FeO}_{\mathrm{T}}$ contents as tonalite, but have slightly higher $\mathrm{CaO}$ contents and much more variable contents of 
Table 2. Light enclave modal proportion and major-element composition.

\begin{tabular}{|c|c|c|c|c|c|c|}
\hline Enclave type & $\begin{array}{c}\text { Carbonate- } \\
\text { bearing }\end{array}$ & & $\begin{array}{l}\text { Quartzo- } \\
\text { feldspathic }\end{array}$ & & Light & \\
\hline Mineralogy & Model (\%) & & & & & \\
\hline Quartz (OZ) & $60-80$ & & 60 & & 35 & \\
\hline Plagioclase (Pl) & $<5$ & & & & & \\
\hline Alkali Feldspar (Kf) & $0-5$ & & 20 & & 20 & \\
\hline Biotite (Bt) & $0-5$ & & $<5$ & & 10 & \\
\hline Amphibole (Am) & $0-5$ & & & & & \\
\hline \multicolumn{7}{|l|}{ Fe-oxides (Ox) } \\
\hline Diopside (Di) & $0-20$ & & 15 & & 30 & \\
\hline Wollastonite (Wo) & $0-30$ & & & & & \\
\hline Calcite (Cc) & $0-15$ & & $<5$ & & $<5$ & \\
\hline \multirow[t]{2}{*}{ Clinozoisite $(\mathrm{Cz})$} & $0-15$ & & $<1$ & & $<5$ & \\
\hline & & $\begin{array}{l}1 \mathrm{SD} \\
n=8\end{array}$ & & $n=1$ & & $n=4$ \\
\hline $\mathrm{SiO}_{2}($ wt. $\%)$ & 76.7 & 9 & 65.6 & & 57.3 & 8.03 \\
\hline $\mathrm{TiO}_{2}$ & 0.28 & 0.19 & 0.75 & & 0.97 & 0.23 \\
\hline $\mathrm{Al}_{2} \mathrm{O}_{3}$ & 8.78 & 3.72 & 15.8 & & 20.9 & 5.43 \\
\hline $\mathrm{Cr}_{2} \mathrm{O}_{3}$ & $<0.01$ & 0 & 0.01 & & 0.01 & 0 \\
\hline $\mathrm{FeO}_{\mathrm{T}}$ & 2.96 & 2.33 & 5.93 & & 6.4 & 0.45 \\
\hline $\mathrm{MgO}$ & 0.16 & 0.17 & 0.09 & & 0.09 & 0.02 \\
\hline $\mathrm{MnO}$ & 0.85 & 0.53 & 1.48 & & 1.71 & 0.31 \\
\hline $\mathrm{CaO}$ & 8.16 & 5.93 & 4.53 & & 3.75 & 1.18 \\
\hline $\mathrm{Na}_{2} \mathrm{O}$ & 1.58 & 1.01 & 3.22 & & 3.45 & 0.18 \\
\hline $\mathrm{K}_{2} \mathrm{O}$ & 0.46 & 0.58 & 2.16 & & 1.44 & 2.32 \\
\hline $\mathrm{P}_{2} \mathrm{O}_{5}$ & 0.07 & 0.05 & 0.18 & & 0.2 & 0.02 \\
\hline Total & 100 & & 99.75 & & 96.22 & \\
\hline
\end{tabular}
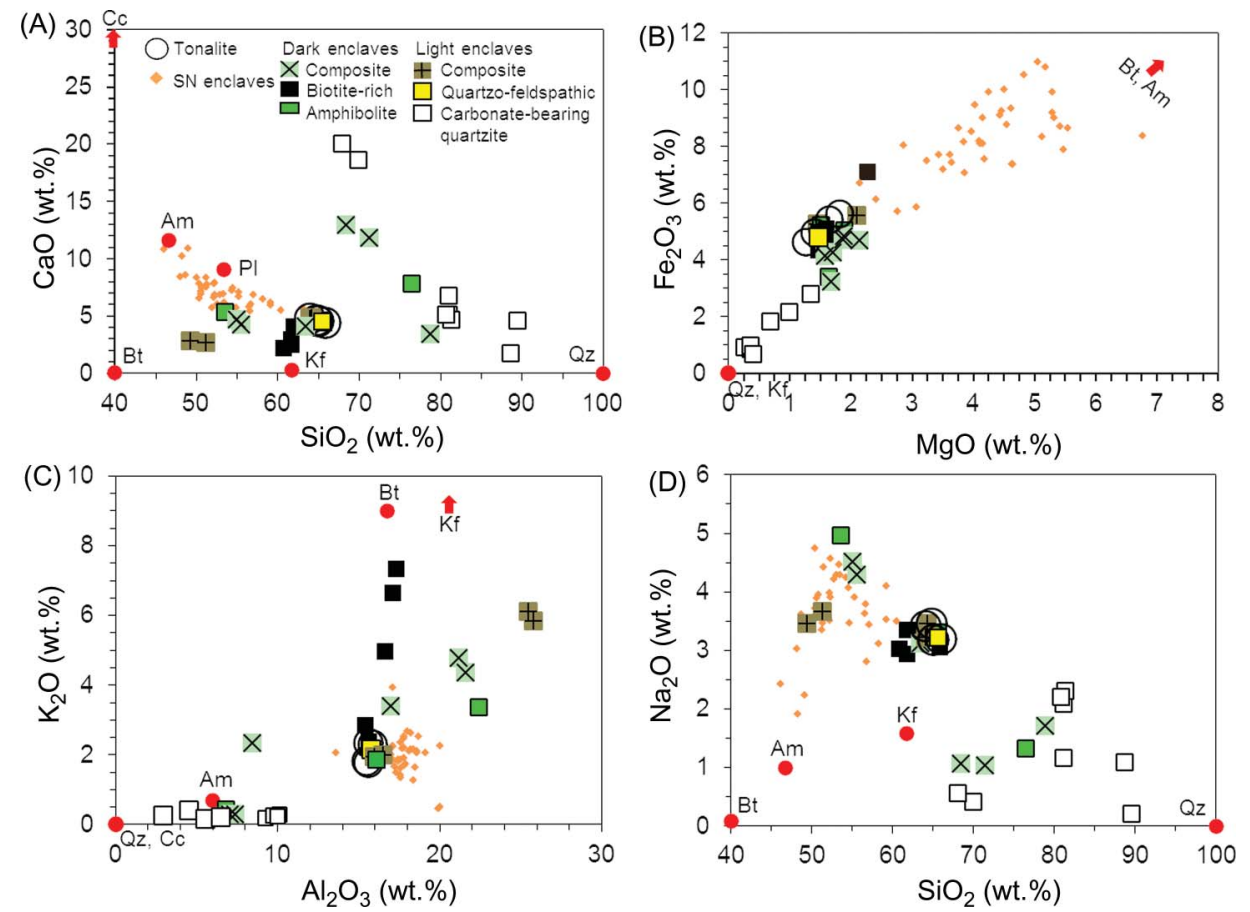

Figure 5. Whole-rock major-element compositions of metasedimentary enclaves and the host tonalite. (A) $\mathrm{SiO}_{2}$ vs. $\mathrm{CaO}$ wt.\%, (B) $\mathrm{MgO}$ vs. $\mathrm{FeO}_{\mathrm{T}}$ wt.\%, (C) $\mathrm{Al}_{2} \mathrm{O}_{3}$ vs. $\mathrm{K}_{2} \mathrm{O}$ wt.\%, and (D) $\mathrm{SiO}_{2}$ vs. $\mathrm{Na}_{2} \mathrm{O}$ wt.\%. The compositions of igneous enclaves from the Sierra $\mathrm{Nevada}$ are plotted in the orange fields. Mineral abbreviations are as follows: Qz $=$ Quartz, $\mathrm{Cc}=$ Calcite, Am $=$ Amphibole, Bt $=\mathrm{Biotite}$, $\mathrm{Pl}=$ Plagioclase, $\mathrm{Kf}=\mathrm{K}$-Feldspar. 
$\mathrm{SiO}_{2}, \mathrm{Al}_{2} \mathrm{O}_{3}$, and alkalis. Composite dark enclaves show compositional characteristics intermediate between biotiterich and amphibole-rich dark enclaves with the exception of two with $\mathrm{CaO}$ contents as high as 10 wt.\% (Table 3).

Light enclaves with quartzo-feldspathic protoliths (containing alkali feldspar) are compositionally similar to the tonalite and the biotite-rich dark enclaves. Light enclaves containing carbonates are enriched in $\mathrm{Si}$ and poor in $\mathrm{Al}, \mathrm{Fe}, \mathrm{Mg}$, and alkalis. $\mathrm{SiO}_{2}$ contents range up to 88 wt.\% (Table 4). Light enclaves in a $\mathrm{CaO}$ versus $\mathrm{SiO}_{2}$ plot appear to fall along mixing trends between quartz and calcite with a small contribution from K-Al bearing phases like biotite and alkali feldspar (Figure 5). Composite light enclaves, which contain feldspar-bearing and carbonatebearing zones, have bulk compositions similar to tonalite and biotite-rich enclaves, with some showing correlated enrichments in $\mathrm{K}_{2} \mathrm{O}$ and $\mathrm{Al}_{2} \mathrm{O}_{3}$ due to the presence of biotite and alkali feldspar.

Many of these similarities and differences can also be seen in a ternary diagram of $\mathrm{Na}+\mathrm{K}, \mathrm{Ca}+\mathrm{Mg}$, and Al (Figure 6). Here, it can be seen that biotite-rich dark enclaves and light enclaves of pelitic origin have compositions similar to tonalite. There appears to be a trend towards calcite displayed by the light enclaves as well as by the amphibole-rich and composite dark enclaves. Also displayed in the biotite-rich dark enclaves is a mixing trend with alkali feldspar.

For comparison, we have also plotted the majorelement compositions of mafic enclaves from the Sierra Nevada. These show some differences between the PRB dark enclaves and Sierra Nevada mafic enclaves. Generally, the mafic enclaves have less variable compositions. They have greater $\mathrm{Fe}$ and $\mathrm{Mg}$ contents than metasedimentary enclaves of all varieties and less $\mathrm{Si}$ (Figure $5 \mathrm{~A}$ ). $\mathrm{K}_{2} \mathrm{O}$ and $\mathrm{CaO}$ contents in mafic enclaves are slightly lower than in metasedimentary dark enclaves. $\mathrm{Na}_{2} \mathrm{O}$ contents in mafic enclaves are similar to or higher than that of metasedimentary enclaves.

\subsubsection{Whole-rock trace elements}

4.2.2.1. Enclaves. Trace element compositions in dark and light enclaves, normalized to bulk continental crust (BCC; Rudnick and Fountain 1995), overlap in absolute and relative abundances. In general, trace element abundances of both dark and light enclaves are subparallel to BCC.

We first discuss the dark enclaves. Biotite-rich dark enclaves tend to have the highest concentrations of trace elements, with one of the biotite-rich enclaves containing the highest rare earth element (REE) abundances of all the enclaves (Figure 7A). As expected, the biotite-rich enclaves contain the highest concentrations of large ion lithophile elements (LILEs), notably $\mathrm{Rb}$ and $\mathrm{Ba}$. Those with the highest levels of $\mathrm{Rb}$ and $\mathrm{Ba}$ also have the highest REE abundances. Biotite-rich enclaves also have low $\mathrm{Sr} / \mathrm{Nd}$ and $\mathrm{CaO}$ wt.\% (Figure $8 \mathrm{~A}$ ). The amphibolite enclaves generally have lower trace element abundances than those of the biotite-rich enclaves. Those with low $\mathrm{K}$ and $\mathrm{Al}$ have the lowest REE abundances. In Figure 8A, samples with low $\mathrm{K}$ and $\mathrm{Al}$ have the highest $\mathrm{CaO}$ wt.\% and $\mathrm{Sr} / \mathrm{Nd}$. Those with high $\mathrm{K}$ and $\mathrm{Al}$, due to the occurrence of biotite, have higher REE abundances and are intermediate between the low $\mathrm{K}$ and $\mathrm{Al}$ amphibolites and the biotite-rich enclaves. These samples are also characterized by low $\mathrm{CaO}$ and $\mathrm{Sr} / \mathrm{Nd}$ (Figure 8A). The dark composite enclaves, which consist of discrete biotite-rich and amphibole-rich bands, share trace element characteristics intermediate between biotite-rich and amphibolite enclaves (Figure 7A). Two of the composite dark enclaves have high $\mathrm{CaO}$ wt. $\%$ and $\mathrm{Sr} / \mathrm{Nd}$ and low $\mathrm{Ba}$, while the remaining four samples have lower $\mathrm{CaO}$ and $\mathrm{Sr} / \mathrm{Nd}$ and higher $\mathrm{Ba}$ (Figures $8 \mathrm{~A}$ and $8 \mathrm{~B})$.

As for the light enclaves, the carbonate-bearing quartzites contain the least amount of trace elements, which is somewhat expected because carbonates and quartz are known to be very poor in trace elements (Figure 7B). Carbonate-bearing quartzite enclaves are characterized by high $\mathrm{Sr} / \mathrm{Nd}$ and low $\mathrm{Ba}$ (Figures $8 \mathrm{~A}$ and $8 \mathrm{~B}$ ). Most samples have similar abundance patterns compared to $\mathrm{BCC}$ with the exception of the most carbonate-rich samples, which are highly depleted in $\mathrm{Rb}$ and $\mathrm{Ba}$ and enriched in $\mathrm{Sr}$ (the most carbonate-rich samples have $\mathrm{Sr}>2000 \mathrm{ppm}$ ). $\mathrm{The} \mathrm{Sr} / \mathrm{Nd}$ ratios of all the carbonate-bearing samples are slightly to significantly higher than those of BCC and the quartzo-feldspathic enclaves. Quartzo-feldspathic enclaves are enriched in LILE and depleted in Sr light composite enclaves are similar in trace element abundance pattern to the metapelites, but their absolute abundances vary considerably (Figure 7B). In particular, the most trace element-enriched samples show a pronounced depletion in $\mathrm{Sr}$ relative to Nd. Quartzo-feldspathic enclaves and light composite enclaves both have low $\mathrm{Sr} / \mathrm{Nd}$ and high $\mathrm{Ba}$ (Figure 8B).

In summary, light and dark enclaves overlap almost completely in trace element composition. In detail, there are also similarities between the subgroups within the dark and light enclaves. Specifically, biotite-rich dark enclaves have trace element abundances that are similar between light composite enclaves and quartzo-feldspathic enclaves. Amphibolite and dark composite enclaves with low $\mathrm{K}$ and $\mathrm{Al}$ have trace element abundances similar to carbonatebearing light enclaves.

4.2.2.2. Tonalite. The host tonalite has trace element abundances that overlap the biotite-rich enclaves. However, the tonalites have LILE contents intermediate between biotite-rich and amphibolite dark enclaves. The tonalite is distinctly richer in trace elements than those of the 


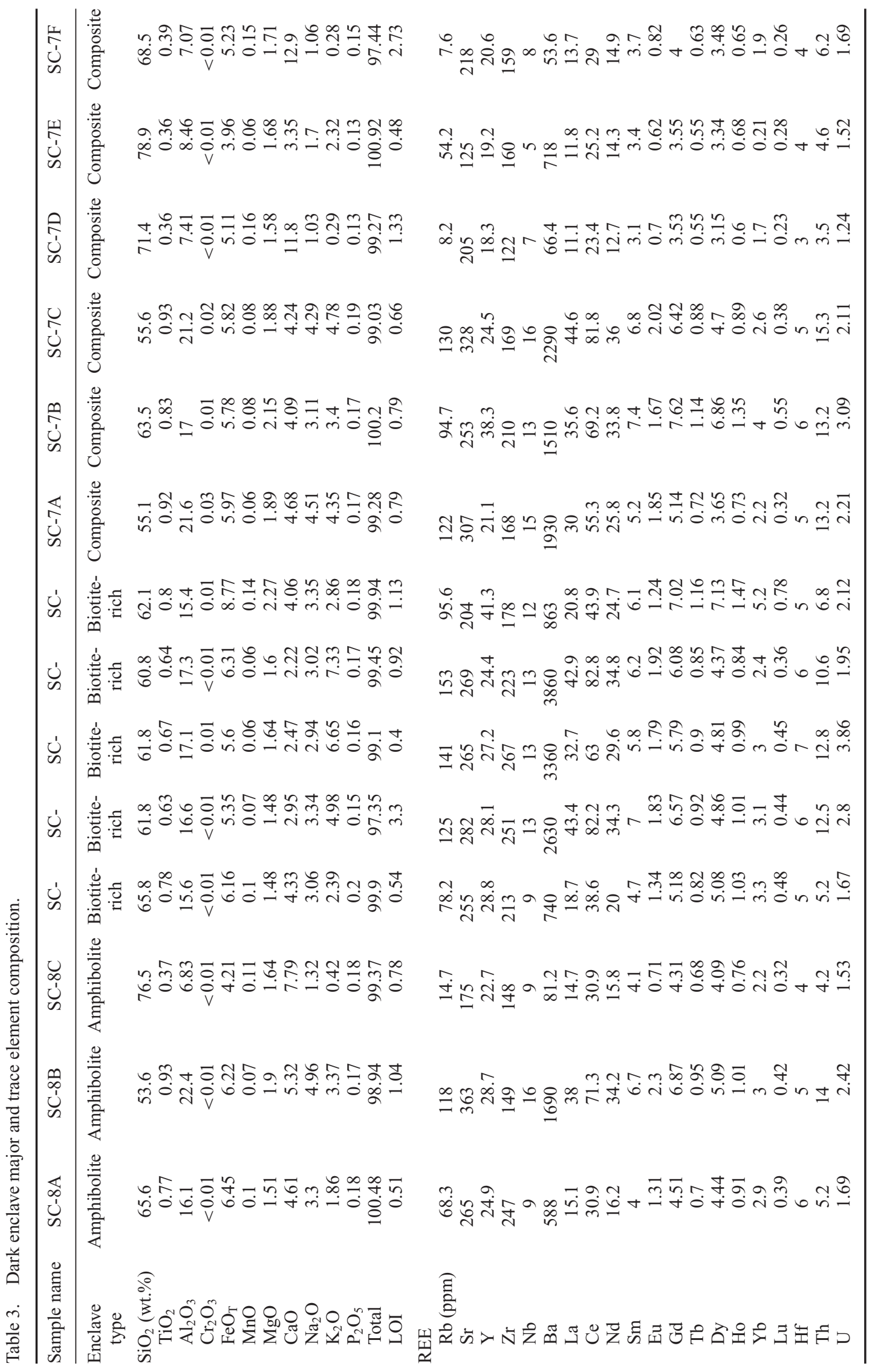




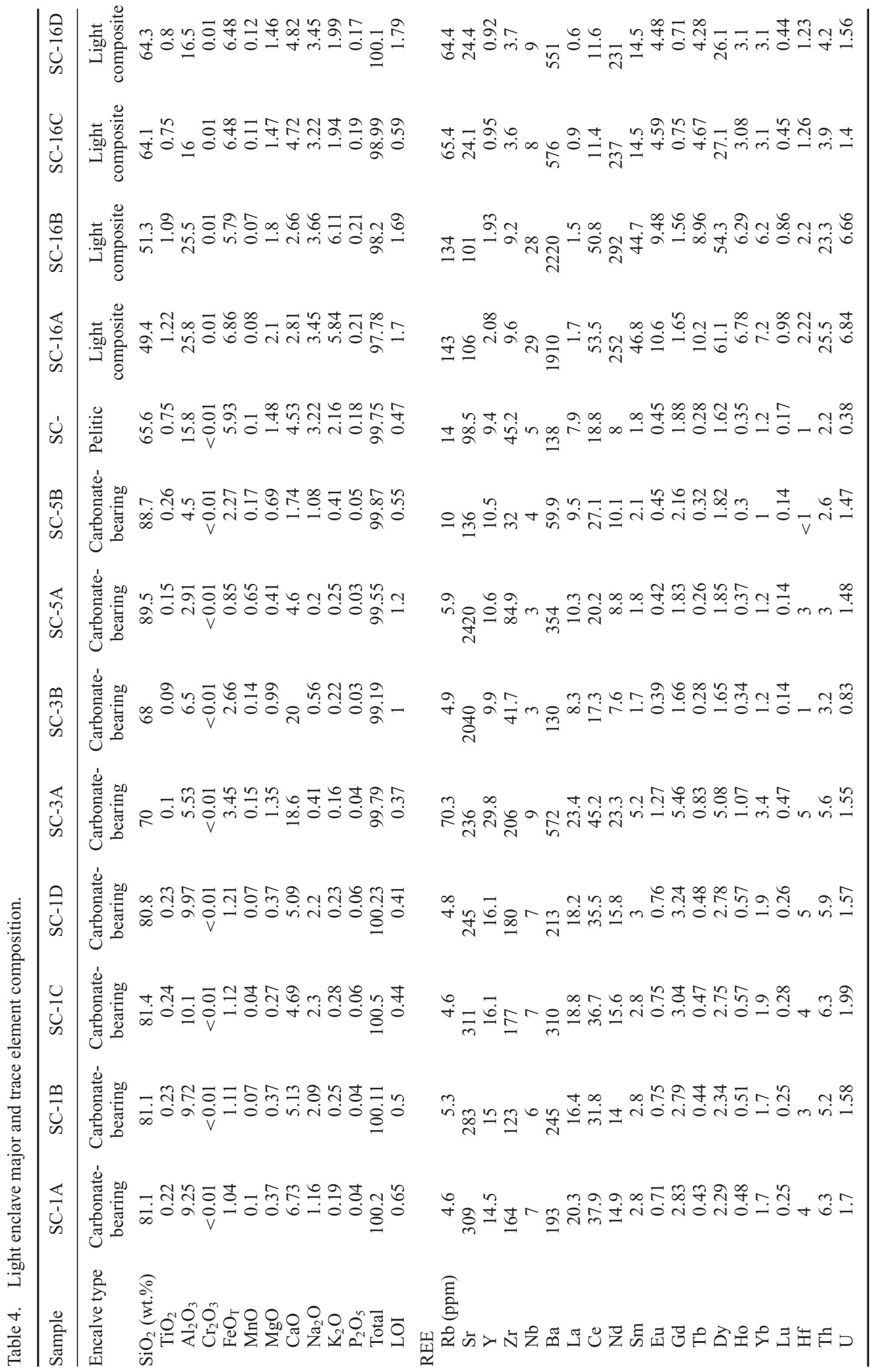




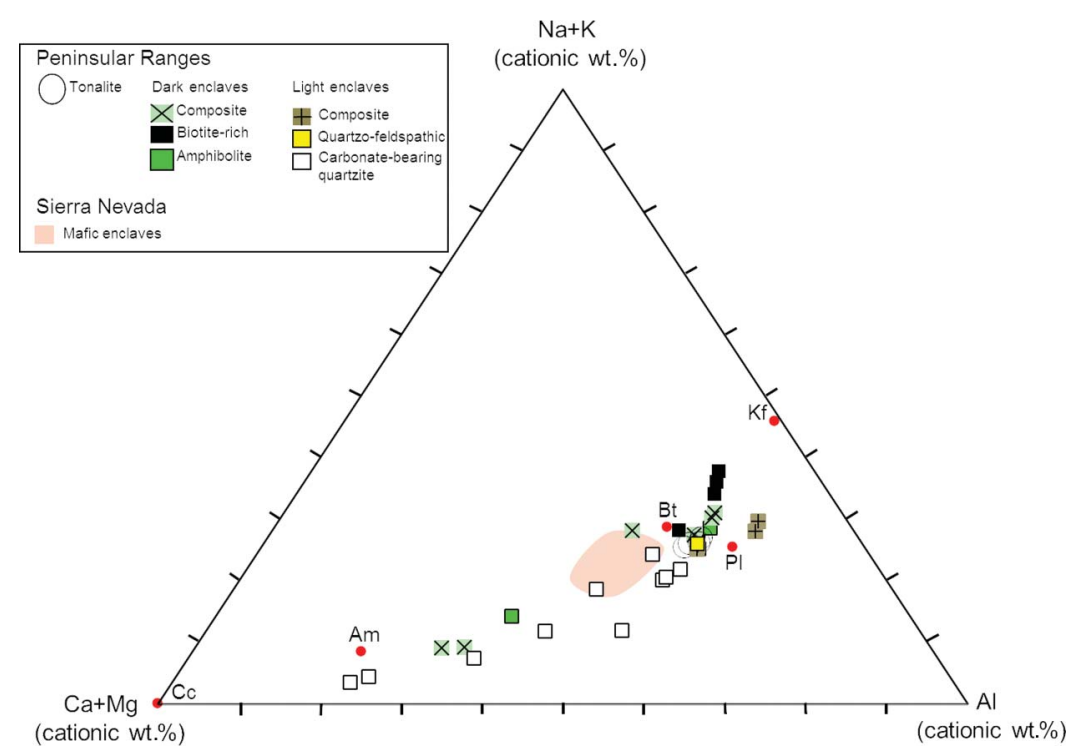

Figure 6. $\mathrm{Ca}+\mathrm{Mg}, \mathrm{Na}+\mathrm{K}, \mathrm{Al}$ (cationic wt.\%) ternary diagram. The shaded field represents enclaves from the Sierra Nevada Batholith. Mineral abbreviations are the same as in Figure 5.

amphibolite enclaves (Figure 7A). We note that there are two clusters of tonalite compositions characterized by slightly different trace element abundances and subtle variations in abundance patterns as seen in different $\mathrm{La} / \mathrm{Yb}$ (Figure 7B).

\subsubsection{Mineral compositions}

Biotite in biotite-rich dark enclaves, composite enclaves, and the host tonalite along with amphiboles in the amphibolite enclaves, carbonate-bearing light enclaves, and the host tonalite were analysed (SC-11, SC-7-2, SC13 and SC-8-2, SC-7-2, SC-4-3, respectively). Majorelement compositions of all biotites, regardless of their host, are similar (Table 5). Trace element abundances of all biotites are generally similar with a few notable exceptions. Specifically, Cr, Sc, V, and Ni contents in biotites from the dark enclaves are generally higher than those of their host tonalite. The overall trace element abundance patterns of the biotites, not surprisingly, are characterized by extreme depletions in REEs, Th, and $U$, but show strong relative enrichments in the high field strength elements (HFSEs) like $\mathrm{Nb}, \mathrm{Ta}, \mathrm{Zr}$, and $\mathrm{Hf}$ (Table 5). We note, however, that the enrichment in HFSEs could be due to the presence of microscopic crystals of Fe-Ti oxide inclusions in the biotite, which could not be completely avoided during laser ablation analysis.

Amphibole compositions are shown in Tables 6 and 7. Amphiboles are much more enriched in trace elements than that of biotites. In particular, they are characterized by relative enrichments in MREE and HREE but depletions in LREEs and LILEs (Figure 9). The amphiboles are also characterized by strongly negative Eu anomalies. Like biotites, amphiboles in enclaves and the host tonalite have similar trace element abundances.

Mafic minerals provide important controls on the trace element abundances of both igneous and metasedimentary dark enclaves. In igneous enclaves, mafic minerals such as amphibole, biotite, and magnetite are reservoirs for trace elements. Enrichments of HREE in enclaves can be attributed to amphibole, which sequesters REEs during the equilibration between dark enclaves and their host granitoid (Barbarin 1990; Dorais et al. 1990; Donaire et al. 2005). Growth of other minerals can also affect the diffusion of trace elements (e.g. Mn and $\mathrm{Zn}$ in Fe-Ti oxides; HREE and $\mathrm{P}$ in apatite) from host granitoid to enclave (Blundy and Sparks, 1992; Wiebe et al. 1997). Mineral assemblage in metasedimentary enclaves plays a similar role in overall trace element abundances, which vary widely. A pronounced characteristic of biotite-rich enclaves is their abundance in LILE, a result of their high biotite modal abundance (Figures 7A and 9). The abundance of trace elements in amphibolite and dark composite enclaves is more heterogeneous than that of biotite-rich enclaves and varies as a function of how $\mathrm{K}$ and $\mathrm{Al}$ rich the enclaves are. Amphibole is abundant in REE but contains low LILE (Figure 9). Consequently, the amphibolite and composite enclaves that are more abundant in LILE are also more abundant in $\mathrm{K}$ and $\mathrm{Al}$.

\section{Discussion}

\subsection{Protolith lithologies for the various enclave types}

The mineralogy of the enclaves depends on wholerock major-element composition, which is a function of protolith composition and changes in composition 

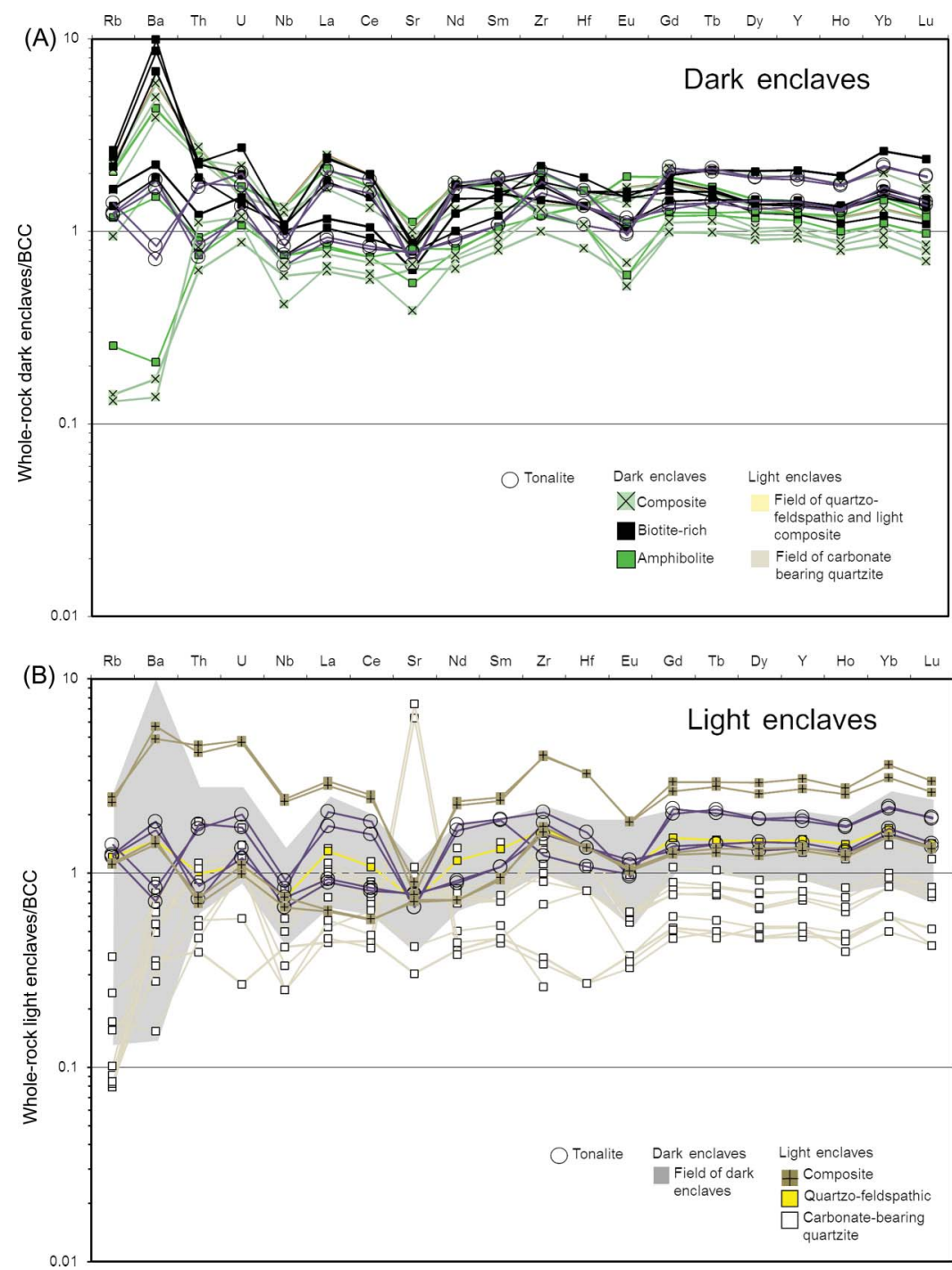

Figure 7. Trace element compositions of enclaves and the host tonalite. (A) Tonalite and dark enclaves are plotted with carbonatebearing and quartzo-feldspathic enclaves represented by the two shaded regions in the background. (B) Trace element abundances of light enclaves with dark enclaves in the shaded region. Samples are normalized to bulk continental crust (Rudnick and Fountain 1995). Large ion lithophile elements are on the left, and rare earth elements from left to right are in order of decreasing ionic radius.

associated with open-system processes, such as physical mixing or diffusion. The fact that the whole-rock major and trace element compositions overlap between the light and dark enclaves suggests that they might have had similar protoliths, but have since experienced varying degrees of thermal metamorphism and chemical equilibration with the host tonalite magma.

The light enclaves are probably the least modified and provide the temporally closest snapshot of the original composition and mineralogy of the protolith. For example, the carbonate-bearing quartzite enclaves have major-element compositions that can be explained by physical mixing of calcite and quartz. In some cases, the calcite is preserved, but in most cases, the calcite has reacted with quartz to form wollastonite. Biotite- and alkali feldspar-bearing light enclaves are similar in majorelement composition to shales and can be classified as quartzo-feldspathic. The light composite enclaves contain distinct bands of quartzo-feldspathic and carbonate-rich layers, which can be explained as original compositional layering in the protolith. In some of these samples, the carbonate has reacted with quartz and biotite to form diopside (Figure 4).

Dark enclaves can also be distinguished by protolith type. For example, the amphibolite enclaves are similar in major-element composition to the carbonate-bearing light enclaves even though the amphibolites do not contain carbonate. Those amphibolites with high $\mathrm{K}$ and $\mathrm{Al}$, due to the presence of small amounts of biotite, may have had a feldspar-rich component in their protoliths. Biotite-rich 

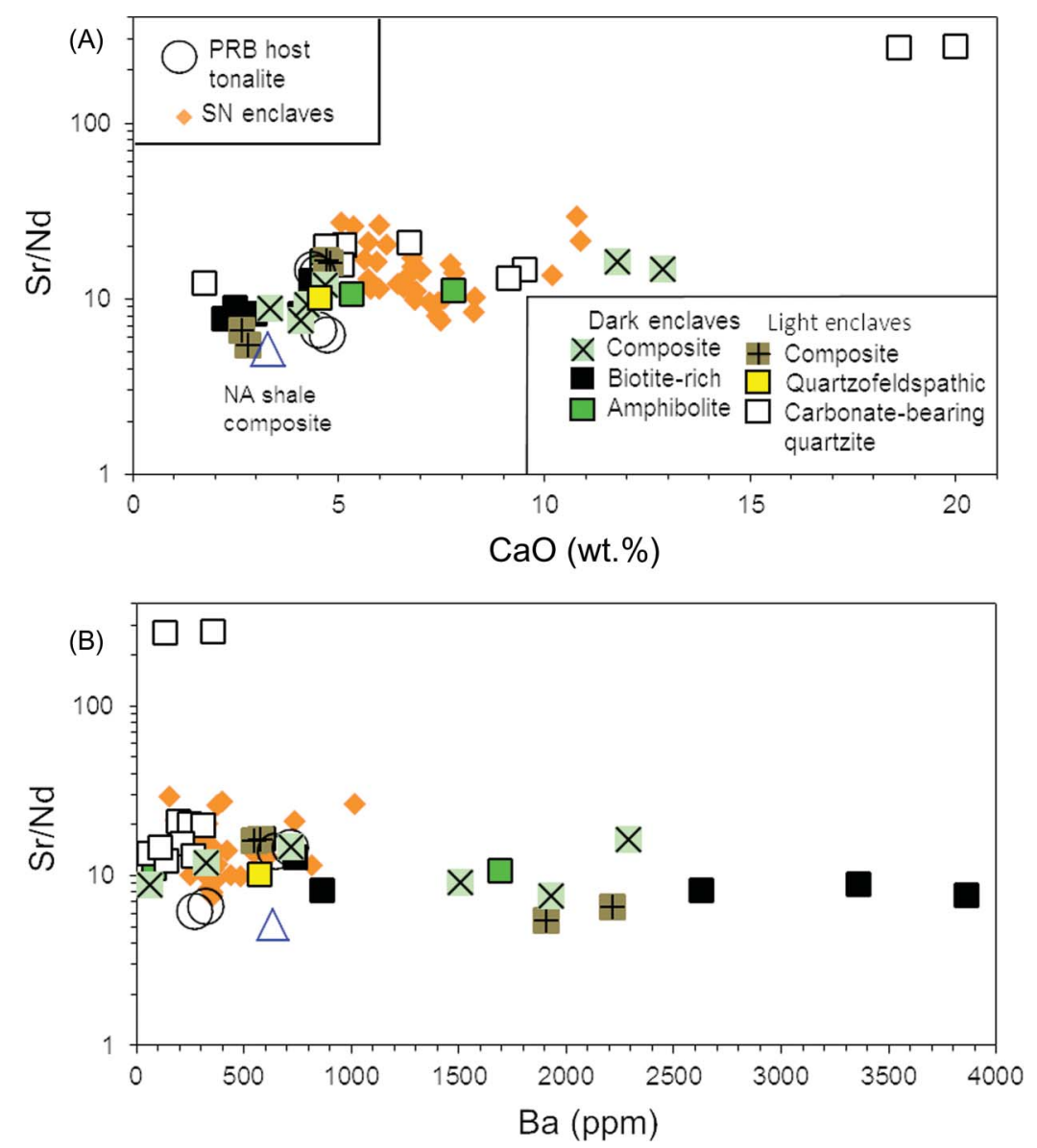

Figure 8. $\mathrm{Sr} / \mathrm{Nd}$ vs. (A) $\mathrm{CaO}$ wt.\% and (B) $\mathrm{Ba}(\mathrm{ppm})$ Sierra Nevada enclaves are represented by the orange-shaded field. $\mathrm{Sr} / \mathrm{Nd}$ is on a log scale.

enclaves are similar in major-element composition to the light quartzo-feldspathic enclaves. However, the strongest evidence that the protoliths of the dark enclaves are metamorphic rocks, not magmas, is the presence of compositional banding in the composite dark enclaves.

The mineralogic changes can be explained by a combination of closed-system thermal metamorphism and open-system metamorphism. Based on our petrographic analyses, we envision the following sequence of reactions. Carbonate-bearing enclaves first undergo isochemical metamorphism involving decarbonation of carbonates to form wollastonite or diopside:

$$
\begin{gathered}
\mathrm{CaCO}_{3}+\mathrm{SiO}_{2}=\mathrm{CaSiO}_{3}+\mathrm{CO}_{2}, \\
\mathrm{CaMg}\left(\mathrm{CO}_{3}\right)_{2}+2 \mathrm{SiO}_{2}=\mathrm{CaMgSi}_{2} \mathrm{O}_{6}+2 \mathrm{CO}_{2} .
\end{gathered}
$$

This reaction appears to occur simultaneously throughout the enclave, consistent with closed-system thermal metamorphism. Pyroxene formation is followed by amphibole formation, which begins first on the rims of the enclave, suggesting that the mineralogy is controlled by spatial variations in the composition of the system as a result of open-system mass exchange. For example, one open-system reaction is

$$
\begin{aligned}
& 2 \mathrm{CaMgSi}_{2} \mathrm{O}_{6}+3 \mathrm{MgO}+4 \mathrm{SiO}_{2}+\mathrm{H}_{2} \mathrm{O} \\
& =\mathrm{Ca}_{2} \mathrm{Mg}_{5} \mathrm{Si}_{8} \mathrm{O}_{22}(\mathrm{OH})_{2},
\end{aligned}
$$

where $\mathrm{MgO}, \mathrm{SiO}_{2}$, and $\mathrm{H}_{2} \mathrm{O}$ are oxide components in the fluid phase. This reaction shows that increased $\mathrm{MgO}$, $\mathrm{SiO}_{2}$, or $\mathrm{H}_{2} \mathrm{O}$ activity will enhance amphibole formation at the expense of diopside. One possibility is that the $\mathrm{CO}_{2}$ liberated from the above decarbonation reactions gradually diffuses into the tonalite host, while $\mathrm{H}_{2} \mathrm{O}$ in the tonalite diffuses into the enclave. This results in an increase in $\mathrm{H}_{2} \mathrm{O}$ activity (with decreasing $\mathrm{CO}_{2}$ activity) in the enclave, beginning from the rim and eventually penetrating the enclave interior, after which all diopside is reacted to form amphibole. The last stage in our sequence is the formation of biotite from amphibole. This requires the introduction of $\mathrm{K}_{2} \mathrm{O}$, which, in the case of the carbonate-bearing quartzites, derives from 


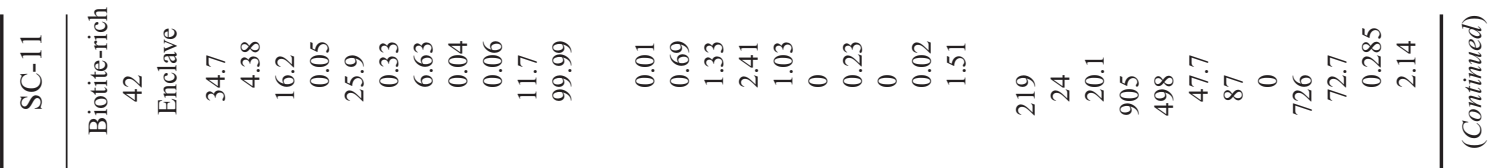

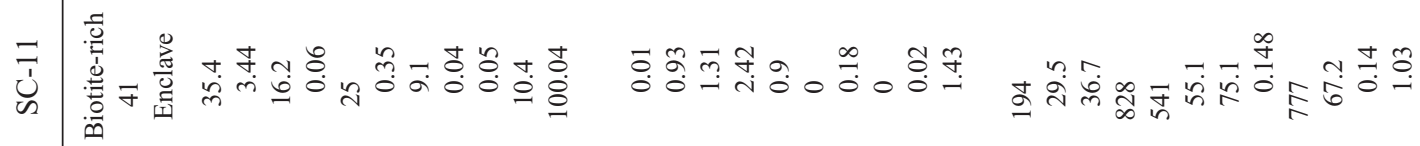

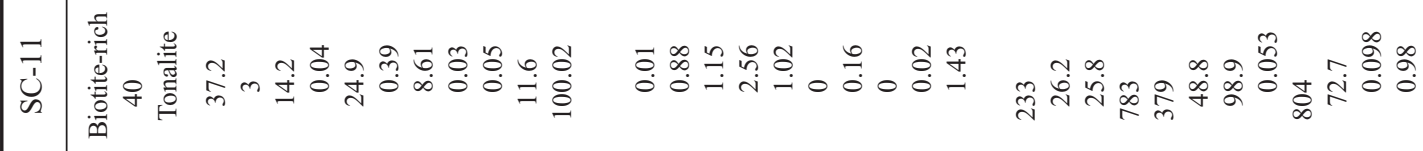

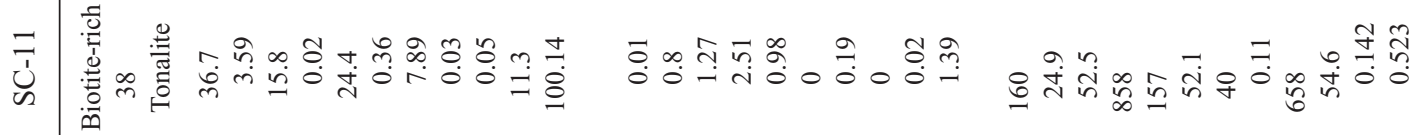

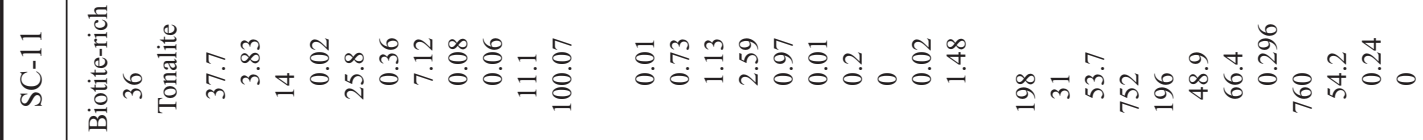

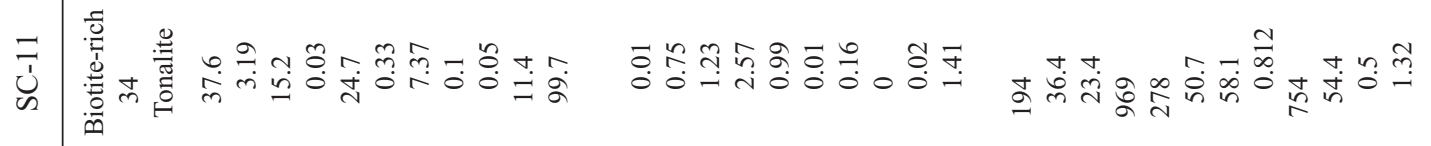

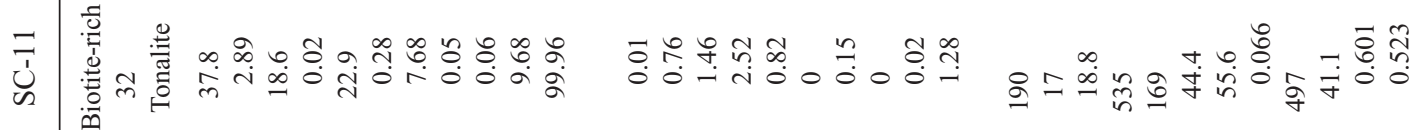

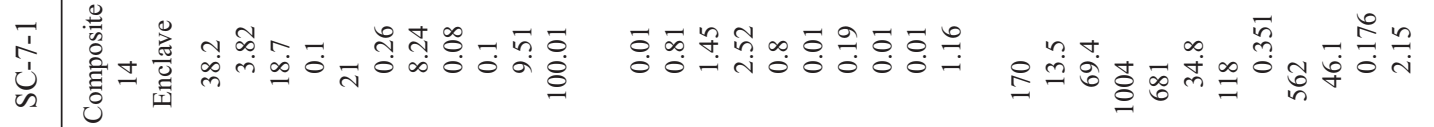

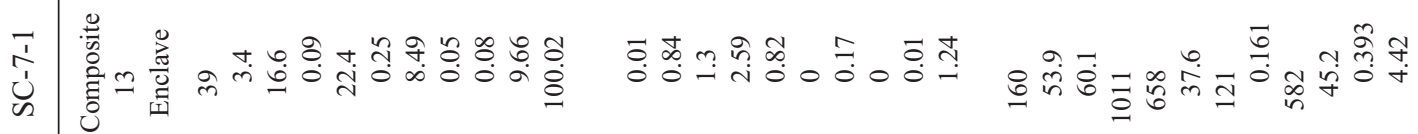

(2)

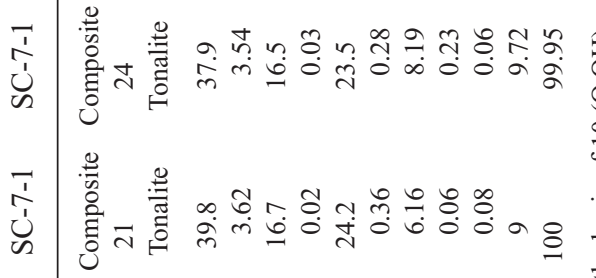

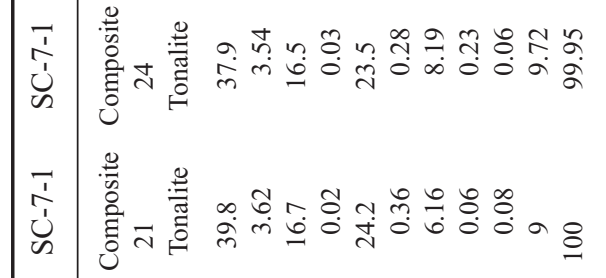

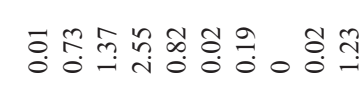

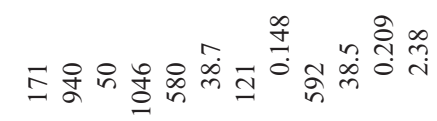

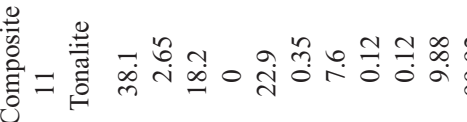

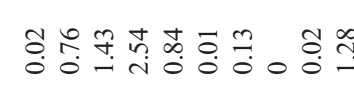

ถุ

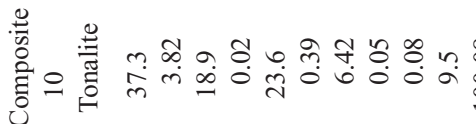

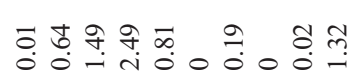

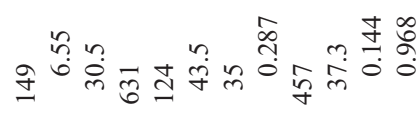

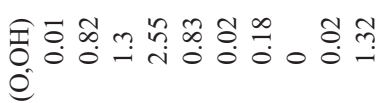

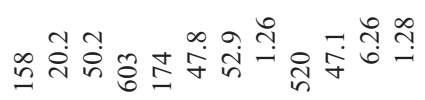

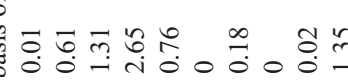

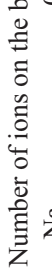

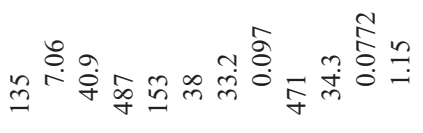




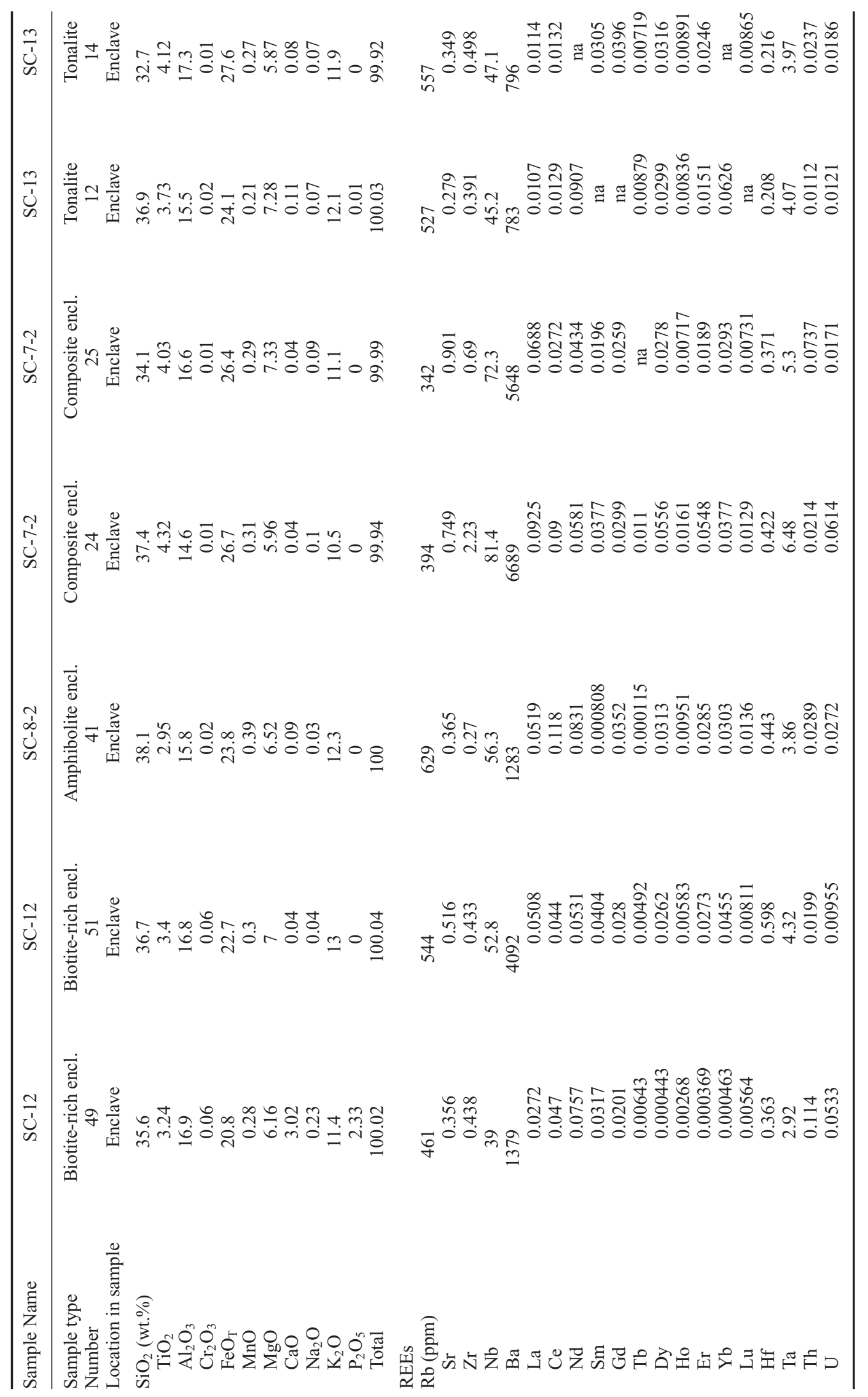


International Geology Review

Table 6. Major and trace element composition of amphibole in dark enclaves.

\begin{tabular}{|c|c|c|c|c|}
\hline Sample name & $\mathrm{SC}-8-2$ & $\mathrm{SC}-7-2$ & SC-8-2 & SC-8-2 \\
\hline Sample type & Amphibolite enclave & Composite enclave & Tonalite & Tonalite \\
\hline Number & 31 & 43 & 14 & 18 \\
\hline Location in sample & Enclave & Enclave & Tonalite & Tonalite \\
\hline $\mathrm{SiO}_{2}(\mathrm{wt} . \%)$ & 53.1 & 53.2 & 55 & 54.9 \\
\hline $\mathrm{TiO}_{2}$ & 1.32 & 0.2 & 0.1 & 0.13 \\
\hline $\mathrm{Al}_{2} \mathrm{O}_{3}$ & 9.11 & 2.02 & 1.42 & 1.28 \\
\hline $\mathrm{Cr}_{2} \mathrm{O}_{3}$ & 0.01 & 0.03 & 0.03 & 0.01 \\
\hline $\mathrm{FeO}_{\mathrm{T}}$ & 14.2 & 18.7 & 19.5 & 18.7 \\
\hline $\mathrm{MnO}$ & 0.27 & 0.68 & 0.73 & 0.65 \\
\hline $\mathrm{MgO}$ & 7.47 & 10.7 & 10.8 & 11.1 \\
\hline $\mathrm{CaO}$ & 12.2 & 14 & 12 & 12.7 \\
\hline $\mathrm{Na}_{2} \mathrm{O}$ & 1.74 & 0.22 & 0.19 & 0.14 \\
\hline $\mathrm{K}_{2} \mathrm{O}$ & 0.48 & 0.15 & 0.11 & 0.07 \\
\hline $\mathrm{P}_{2} \mathrm{O}_{5}$ & 0.01 & 0.01 & 0 & 0.35 \\
\hline Total & 99.91 & 99.91 & 99.88 & 100.03 \\
\hline \multicolumn{5}{|l|}{ REEs } \\
\hline $\mathrm{Rb}(\mathrm{ppm})$ & 1.22 & 0.149 & 0.582 & 3.3 \\
\hline $\mathrm{Sr}$ & 62.2 & 2.99 & 14.7 & 8.89 \\
\hline $\mathrm{Zr}$ & 112 & 1.84 & 3.92 & 4.86 \\
\hline $\mathrm{Nb}$ & 0.971 & 0.0604 & 0.32 & 3.03 \\
\hline $\mathrm{Ba}$ & 3.73 & 0.26 & 3.92 & 13.3 \\
\hline $\mathrm{La}$ & 1.04 & 0.384 & 0.245 & 0.475 \\
\hline $\mathrm{Ce}$ & 3.5 & 3.06 & 1.44 & 2.4 \\
\hline $\mathrm{Nd}$ & 7.61 & 6 & 3.53 & 4.99 \\
\hline $\mathrm{Sm}$ & 3.89 & 3.11 & 2.14 & 3.2 \\
\hline $\mathrm{Gd}$ & 6.51 & 4.36 & 4.66 & 5.97 \\
\hline $\mathrm{Tb}$ & 1.06 & 0.756 & 1.02 & 1.3 \\
\hline Dy & 7.35 & 5.7 & 8.69 & 8.36 \\
\hline Но & 1.39 & 1.1 & 2.26 & 1.94 \\
\hline $\mathrm{Er}$ & 3.86 & 2.87 & 8.42 & 5.93 \\
\hline $\mathrm{Yb}$ & 2.79 & 1.94 & 10.2 & 4.64 \\
\hline $\mathrm{Lu}$ & 0.485 & 0.334 & 1.73 & 0.82 \\
\hline Hf & 3.1 & 0.202 & 0.355 & 0.588 \\
\hline $\mathrm{Ta}$ & 0.0518 & 0.0119 & 0.0312 & 0.17 \\
\hline Th & 0.744 & 0.0474 & 0.191 & 0.133 \\
\hline $\mathrm{U}$ & 0.437 & 0.0357 & 0.564 & 0.498 \\
\hline
\end{tabular}

the tonalite. We envisage the following open system reaction:

$$
\begin{array}{r}
6 \mathrm{Ca}_{2} \mathrm{Mg}_{5} \mathrm{Si}_{8} \mathrm{O}_{22}(\mathrm{OH})_{2}+5 \mathrm{AI}_{2} \mathrm{O}_{3}+5 \mathrm{~K}_{2} \mathrm{O}+4 \mathrm{H}_{2} \mathrm{O} \\
=10 \mathrm{KMg}_{3} \mathrm{AISi}_{3} \mathrm{O}_{10}(\mathrm{OH})_{2}+12 \mathrm{CaO}+18 \mathrm{SiO}_{2} .
\end{array}
$$

These concepts can be visualized in Figure 10A, where reactions and stability fields are expressed graphically in the form of activity diagrams at constant temperature and pressure (Helgeson et al. 1969; Brown and Essene 1985; van Marcke de Lummen and Verkaeren 1986; Dyer et al. 2011). For example, increasing $\mathrm{SiO}_{2}$ and $\mathrm{H}_{2} \mathrm{O}$ activity promotes reaction of diopside to amphibole. Increasing $\mathrm{K}_{2} \mathrm{O}$ and decreasing $\mathrm{CaO}$ activities promote reaction of amphibole to biotite, whereas a decrease in $\mathrm{Al}_{2} \mathrm{O}_{3}$ and $\mathrm{H}_{2} \mathrm{O}$ activity increases the stability field of amphibole relative to biotite at a given pressure and temperature. Similar concepts apply to the transformation of quartzo-feldspathic enclaves into biotite-rich dark enclaves. Alkali feldspar can react with $\mathrm{Mg}$ and water to form biotite, either isochemically if the enclave already has $\mathrm{Mg}$ and $\mathrm{H}_{2} \mathrm{O}$ or through open-system introduction of $\mathrm{Mg}$ and $\mathrm{H}_{2} \mathrm{O}$ (Figure 10B):

$$
\mathrm{KAISi}_{3} \mathrm{O}_{8}+3 \mathrm{MgO}+\mathrm{H}_{2} \mathrm{O}=\mathrm{KMg}_{3} \mathrm{AISi}_{3} \mathrm{O}_{10}(\mathrm{OH})_{2} .
$$

The end-product is a biotite-rich dark enclave. Additional reactions observed include the formation of clinozoisite from plagioclase and the formation of titanite by reaction of Fe-Ti oxides with carbonate or wollastonite, but these reactions are of lesser importance than the above-described reactions.

\subsection{Similarities and differences between dark igneous and metasedimentary enclaves}

Given the very similar macroscopic similarities between the dark enclaves of metasedimentary origin investigated here to mafic enclaves typically considered to be of 
Table 7. Major and trace element composition of amphibole in light enclaves.

\begin{tabular}{|c|c|c|c|c|}
\hline Sample name & SC-4-3 & SC-4-3 & SC-4-3 & SC-4-3 \\
\hline Enclave type & Carbonate-bearing & Carbonate-bearing & Carbonate-bearing & Carbonate-bearing \\
\hline Number & 26 & 21 & 17 & 18 \\
\hline Location in sample & Tonalite & Enclave rim & Enclave rim & Enclave rim \\
\hline $\mathrm{SiO}_{2}($ wt.\%) & 46.6 & 46.5 & 50.5 & 51.4 \\
\hline $\mathrm{TiO}_{2}$ & 1.41 & 0.11 & 0.08 & 0.07 \\
\hline $\mathrm{Al}_{2} \mathrm{O}_{3}$ & 5.98 & 4.86 & 3.11 & 1.09 \\
\hline $\mathrm{Cr}_{2} \mathrm{O}_{3}$ & 0 & 0.01 & 0.01 & 0.01 \\
\hline $\mathrm{FeO}_{\mathrm{T}}$ & 24.4 & 27.2 & 23.9 & 18 \\
\hline $\mathrm{MnO}$ & 0.69 & 0.61 & 0.62 & 0.77 \\
\hline $\mathrm{MgO}$ & 7.58 & 7.64 & 8.68 & 5.71 \\
\hline $\mathrm{CaO}$ & 11.6 & 11.9 & 12.5 & 22.5 \\
\hline $\mathrm{Na}_{2} \mathrm{O}$ & 1 & 0.63 & 0.41 & 0.37 \\
\hline $\mathrm{K}_{2} \mathrm{O}$ & 0.7 & 0.47 & 0.19 & 0.08 \\
\hline $\mathrm{P}_{2} \mathrm{O}_{5}$ & 0.01 & 0.01 & 0.01 & 0.01 \\
\hline Total & 99.97 & 99.94 & 100.01 & 100.01 \\
\hline \multicolumn{5}{|c|}{ Number of ions on the basis of $22(\mathrm{O}, \mathrm{OH})$} \\
\hline $\mathrm{Na}$ & 0.28 & 0.18 & 0.11 & 0.1 \\
\hline $\mathrm{Mg}$ & 1.63 & 1.67 & 1.85 & 1.22 \\
\hline $\mathrm{Al}$ & 1.02 & 0.84 & 0.52 & 0.18 \\
\hline $\mathrm{Si}$ & 6.75 & 6.82 & 7.21 & 7.36 \\
\hline $\mathrm{P}$ & 0 & 0 & 0 & 0 \\
\hline $\mathrm{K}$ & 0.13 & 0.09 & 0.03 & 0.01 \\
\hline $\mathrm{Ca}$ & 1.8 & 1.87 & 1.91 & 3.46 \\
\hline $\mathrm{Ti}$ & 0.15 & 0.01 & 0.01 & 0.01 \\
\hline $\mathrm{Cr}$ & 0 & 0 & 0 & 0 \\
\hline $\mathrm{Mn}$ & 0.08 & 0.08 & 0.08 & 0.09 \\
\hline $\mathrm{Fe}$ & 2.95 & 3.33 & 2.85 & 2.15 \\
\hline \multicolumn{5}{|c|}{ Trace elements (ppm) } \\
\hline $\mathrm{Li}$ & 6.24 & 3.6 & 3.17 & 10.4 \\
\hline $\mathrm{P}$ & 45.6 & 44.9 & 52.3 & 58.2 \\
\hline $\mathrm{Sc}$ & 1051 & 150 & 209 & 100 \\
\hline $\mathrm{V}$ & 572 & 306 & 317 & 266 \\
\hline $\mathrm{Cr}$ & 22.5 & 57.1 & 80.6 & 78.7 \\
\hline Co & 45.6 & 143 & 46.3 & 27.5 \\
\hline $\mathrm{Ni}$ & 20.6 & 282 & 20.6 & 10.4 \\
\hline $\mathrm{Cu}$ & 0.342 & 138 & 0.302 & 0.704 \\
\hline $\mathrm{Zn}$ & 659 & 600 & 622 & 480 \\
\hline $\mathrm{Ga}$ & 24.2 & 26.4 & 11 & 6.53 \\
\hline $\mathrm{Zr}$ & 106 & 9.85 & 4.69 & 7.84 \\
\hline
\end{tabular}

magmatic origin, it is worth now examining how igneous and metasedimentary enclaves compare geochemically. For this comparison, we use mafic enclaves from the Sierra Nevada Batholith, which have been interpreted to represent mafic magma fragments entrained in a more felsic magma (Barbarin et al. 1989). These 'igneous' enclaves are plotted on the same major-element diagrams as the metasedimentary enclaves in Figures 5 and 6. It can be seen that many of the dark enclaves have broadly similar major-element compositions as the Sierran mafic enclaves. For example, although $\mathrm{SiO}_{2}$ contents of the dark metasedimentary enclaves are highly variable, many of the biotite-rich and composite dark enclaves have $\mathrm{SiO}_{2}$ contents between 53-63 wt.\%, within the range of Sierran mafic enclaves (45-65 wt.\%). Similarly, there are overlaps in $\mathrm{CaO}, \mathrm{Na}_{2} \mathrm{O}, \mathrm{K}_{2} \mathrm{O}$, and $\mathrm{Al}_{2} \mathrm{O}_{3}$ contents. We also note some similarities in trace elements. Sierran mafic enclaves and the dark metasedimentary enclaves are enriched in transition metals, such as $\mathrm{Sc}, \mathrm{Cr}$, and $\mathrm{Zn}$, relative to the tonalite. $\mathrm{Sr} / \mathrm{Nd}$ ratios, which are a potentially useful tracer for carbonate-bearing protoliths because of the strong preference of $\mathrm{Sr}$ for carbonates, also show some overlap (Figure 8A). The composition of North American Shale Composite is also shown in order to illustrate the similarities between the shale and light sedimentary enclaves.

There are, however, differences. Many of the dark metasedimentary enclaves have $\mathrm{SiO}_{2}$ contents $>70 \mathrm{wt} . \%$, far higher than those of the Sierran mafic enclaves. Dark sedimentary enclaves tend to be slightly lower in $\mathrm{Mg}$ and Fe compared to the Sierran mafic enclaves. $\mathrm{Al}_{2} \mathrm{O}_{3}$ contents 


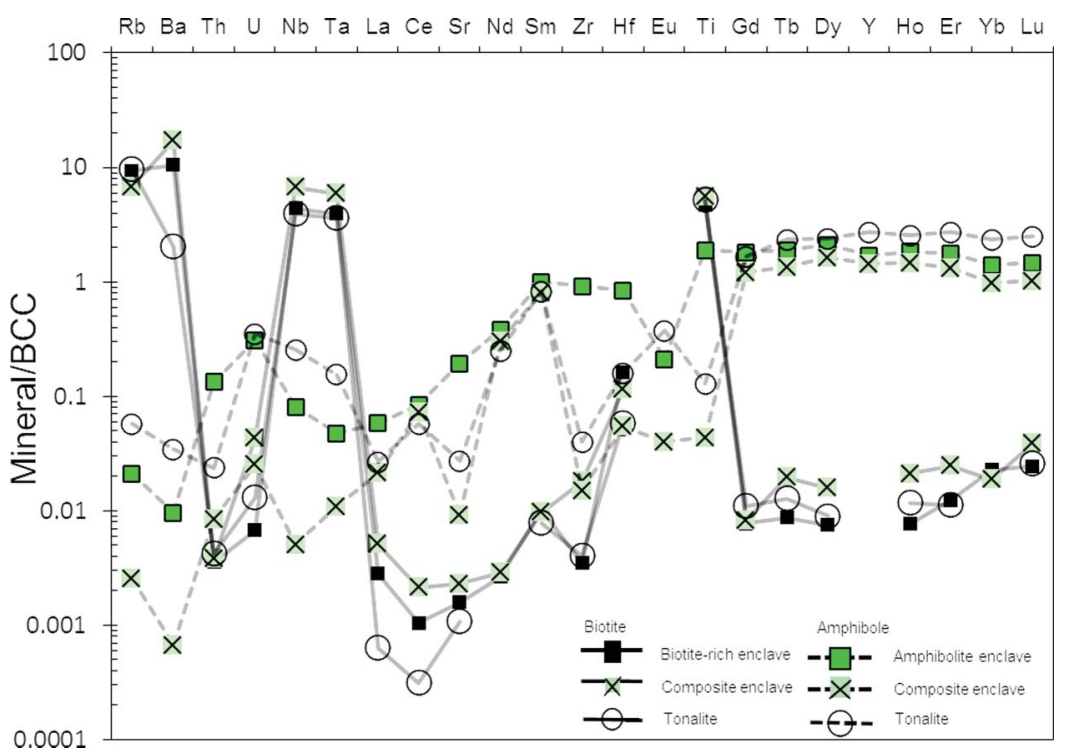

Figure 9. Trace element composition of mafic minerals in dark metasedimentary enclaves and host tonalite. Biotite was analysed in the tonalite, biotite-rich, and dark composite enclaves (SC-13, SC-11, and SC-7-1). Amphibole was analysed in the tonalite, amphibolite, and dark composite enclaves (SC-4-3, SC-8-2, and SC-7-2).

in some of the dark enclaves are $>20 \mathrm{wt} . \%$, which is higher than those of the Sierran mafic enclaves. The most Ca-rich dark metasedimentary enclaves are considerably richer in $\mathrm{CaO}$ than the Sierran mafic enclaves. $\mathrm{Sr} / \mathrm{Nd}$ ratios in these Ca-rich dark metasedimentary enclaves are $\sim 10$ times higher than Sierran mafic enclaves. Ba contents of the dark biotite-rich metasedimentary enclaves are four times higher than those of the most Ba-rich Sierran mafic enclave.

Further trace element differences exist. Dark igneous enclaves have a pronounced enrichment in trace elements relative to their host granitoids, a feature that is not apparent in metasedimentary enclaves (Figure 11). The enrichment of REE in dark igneous enclaves is often explained by the diffusive transfer of REE between enclaves and their host (Orsini et al. 1991; Blundy and Sparks 1992; Tepper and Kuehner 2004). In particular, minerals that are abundant in the dark enclaves, such as amphibole or magnetite, equilibrate with the host and sequester the REEs (Ryerson and Hess 1978; Allen 1991; Blundy and Sparks 1992). Most metasedimentary enclaves do not have hostnormative enrichments in REE as igneous enclaves have. Instead, they are characterized by enrichments in $\mathrm{K}$ and LILE, the extents of which vary as a function of mineralogy (Figures 7A and 11). High K and LILE metasedimentary enclaves are also characterized by having REE abundances that are similar to those of North American Shale Composite values (Taylor et al. 1981; Condie 1993).

We note that, in terms of major elements, the Sierran mafic enclaves tend to fall on relatively narrow linear arrays, which supports a magmatic origin (Reid and Hamilton 1987; Kumar and Rino 2006). For example, in both Sierran mafic enclaves and their magma hosts, $\mathrm{Ca}, \mathrm{Al}$,
$\mathrm{Fe}$, and $\mathrm{Mg}$ contents decrease with increasing $\mathrm{Si}$ (Barbarin et al. 1989; Chen and Williams 1990; Dodge and Kistler 1990). In contrast, the dark metasedimentary enclaves here do not show such coherent major-element systematics. We expand on these concepts in the next section.

\subsection{Using major-element trends in dark enclaves to differentiate between igneous and metasedimentary origins}

It is well-known that the major-element compositions of cumulates, restites, and mafic magma fragments are complementary to their host granitoids, generating continuous linear to near-linear geochemical arrays (White and Chappell 1977; Reid and Hamilton 1987; Dodge and Kistler 1990; Blundy and Sparks 1992). For this reason, it seems likely that the major-element trends seen in metasedimentary enclaves and their host tonalite might be readily distinguishable from the trends of igneous enclaves as discussed in the previous section. To explore this suggestion further in a more quantitative way, we modelled possible cumulates/restites derived from a granitoid magma. To insure applicability to our case study, we took the host tonalite composition of the Domenigoni Valley pluton as starting composition (Table 8). We then used the thermodynamic program, known as MELTS (Ghiorso and Sack 1995), to estimate possible cumulate/restite-liquid pairs. Given the high silica content of the Domenigoni Valley tonalite, we assume that fractional crystallization driven by gravitational segregation of crystals from residual liquid is highly inefficient, and thus, we assume batch equilibration of cumulate/restites with the residual liquid. 
(A)
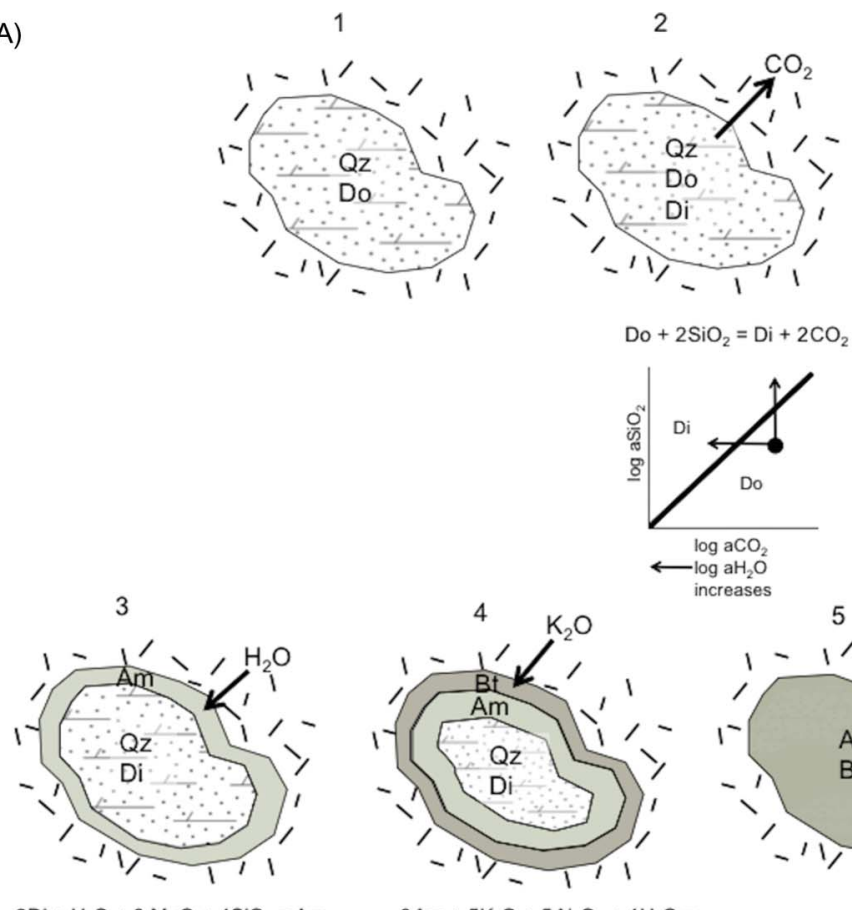

$2 \mathrm{Di}+\mathrm{H}_{2} \mathrm{O}+3 \mathrm{MgO}+4 \mathrm{SiO}_{2}=\mathrm{Am}$

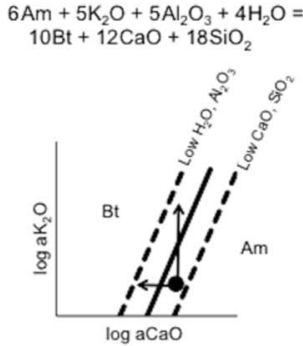

(B)
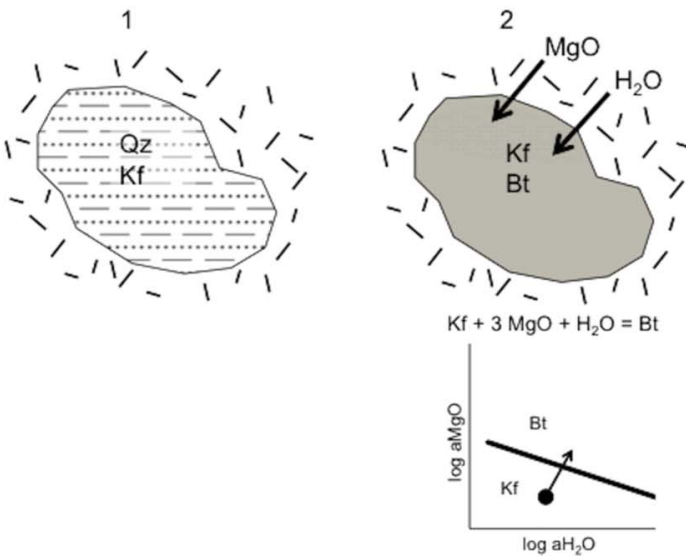

Figure 10. Progression of metamorphic reactions in metasedimentary enclaves. (A) (1) Quartz- and carbonate-rich enclave entrained in a tonalite host. (2) $\mathrm{CO}_{2}$ is released as carbonate and quartz react to form diopside. (3) With the influx of $\mathrm{H}_{2} \mathrm{O}$, the enclave progresses towards amphibole-rich mineralogy. (4) The diffusion of $\mathrm{K}$ from tonalite to enclave results in the formation of biotite. (5) More $\mathrm{K}$ allows biotite to form in the enclave. (B) (1) Quartzo-feldspathic enclaves are rich in K-feldspar. (2) With the influx of $\mathrm{H}_{2} \mathrm{O}$ and $\mathrm{Mg}$, the enclaves progress towards biotite-rich content. Activity diagrams are based on the metamorphic reactions that take place in enclaves. For each metamorphic reaction, the equilibrium constant depends on the activities and stoichiometries of element oxides. The slopes of activity plot curves are determined by rearranging the activities written for a given reaction's equilibrium constant. 


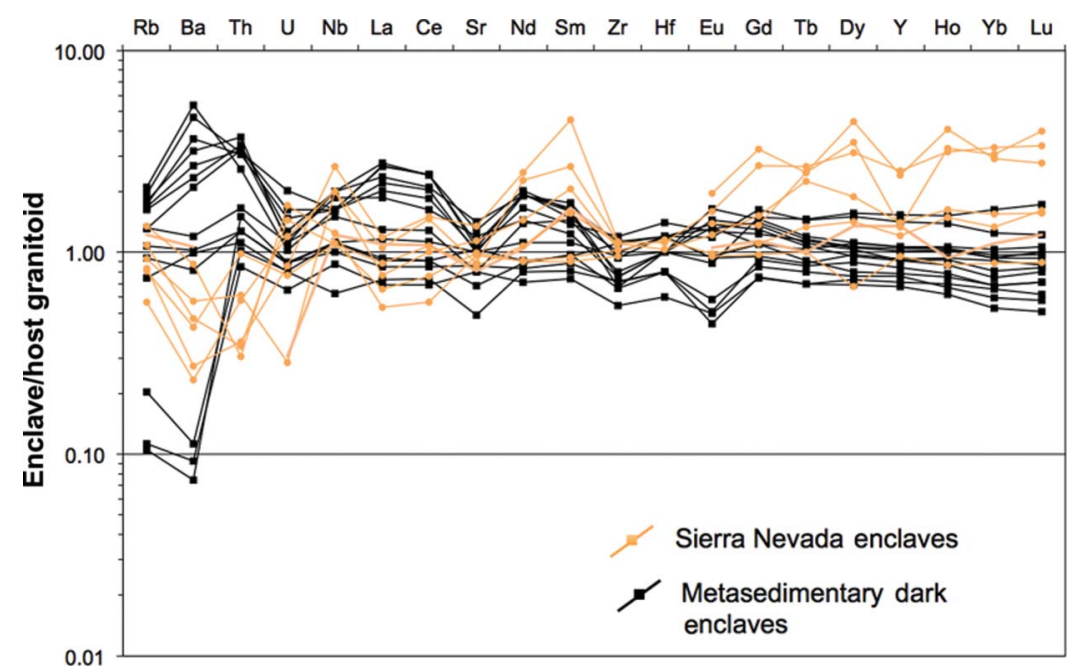

Figure 11. Host-normative trace elements of metasedimentary dark enclaves and Sierra Nevada enclaves. Trace element compositions of metasedimentary dark enclaves from the Peninsular Ranges are normalized to their host tonalite. In the case of Sierra Nevada samples, enclaves are normalized to their respective host granitoid.

Table 8. Host tonalite major and trace element composition.

\begin{tabular}{|c|c|c|c|c|}
\hline Sample name & $\mathrm{SC}-13 \mathrm{~A}$ & $\mathrm{SC}-13 \mathrm{~B}$ & SC-13C & SC-13D \\
\hline Sample type & Tonalite & Tonalite & Tonalite & Tonalite \\
\hline $\mathrm{SiO}_{2}($ wt. $\%)$ & 66.0 & 65.1 & 64.1 & 64.9 \\
\hline $\mathrm{TiO}_{2}$ & 0.64 & 0.74 & 0.87 & 0.86 \\
\hline $\mathrm{Al}_{2} \mathrm{O}_{3}$ & 15.6 & 15.9 & 15.6 & 15.5 \\
\hline $\mathrm{Cr}_{2} \mathrm{O}_{3}$ & $<0.01$ & $<0.01$ & $<0.01$ & $<0.01$ \\
\hline $\mathrm{FeO}_{\mathrm{T}}$ & 5.69 & 6.09 & 6.94 & 6.68 \\
\hline $\mathrm{MnO}$ & 0.1 & 0.11 & 0.14 & 0.13 \\
\hline $\mathrm{MgO}$ & 1.28 & 1.42 & 1.82 & 1.66 \\
\hline $\mathrm{CaO}$ & 4.39 & 4.50 & 4.74 & 4.55 \\
\hline $\mathrm{Na}_{2} \mathrm{O}$ & 3.19 & 3.17 & 3.41 & 3.45 \\
\hline $\mathrm{K}_{2} \mathrm{O}$ & 2.33 & 2.27 & 1.77 & 1.80 \\
\hline $\mathrm{P}_{2} \mathrm{O}_{5}$ & 0.16 & 0.16 & 0.29 & 0.30 \\
\hline Total & 99.38 & 99.46 & 99.68 & 99.83 \\
\hline LOI & 0.72 & 0.63 & 0.60 & 0.55 \\
\hline \multicolumn{5}{|l|}{ REE (ppm) } \\
\hline $\mathrm{Rb}$ & 72.5 & 71.3 & 70.3 & 81.1 \\
\hline $\mathrm{Sr}$ & 255 & 251 & 217 & 217 \\
\hline $\mathrm{Y}$ & 26.9 & 28.6 & 37.1 & 38.9 \\
\hline $\mathrm{Zr}$ & 223 & 195 & 253 & 151 \\
\hline $\mathrm{Nb}$ & 8 & 9 & 10 & 11 \\
\hline $\mathrm{Ba}$ & 719 & 651 & 278 & 328 \\
\hline $\mathrm{La}$ & 16.1 & 16.8 & 37.2 & 31.4 \\
\hline $\mathrm{Ce}$ & 34 & 35.2 & 77.3 & 66.4 \\
\hline $\mathrm{Nd}$ & 17.8 & 18.3 & 35.5 & 33.2 \\
\hline $\mathrm{Sm}$ & 4.2 & 4.2 & 7.4 & 7.3 \\
\hline $\mathrm{Eu}$ & 1.4 & 1.32 & 1.15 & 1.18 \\
\hline Gd & 4.7 & 4.96 & 7.72 & 7.28 \\
\hline $\mathrm{Tb}$ & 0.79 & 0.79 & 1.14 & 1.19 \\
\hline Dy & 4.56 & 5.07 & 6.62 & 6.66 \\
\hline Но & 0.97 & 0.99 & 1.31 & 1.33 \\
\hline $\mathrm{Yb}$ & 3.2 & 3.4 & 4.3 & 4.4 \\
\hline $\mathrm{Lu}$ & 0.45 & 0.47 & 0.64 & 0.63 \\
\hline Hf & 5 & 5 & 6 & 4 \\
\hline Th & 4.1 & 4.8 & 10 & 9.5 \\
\hline $\mathrm{U}$ & 1.9 & 1.69 & 2.44 & 2.84 \\
\hline
\end{tabular}

To estimate different liquid fractions, our batch calculations were performed at temperatures between 720 and $960^{\circ} \mathrm{C}$ for temperature intervals of $30^{\circ} \mathrm{C}$ at a constant pressure of $1 \mathrm{kbar}$ (Table 9). This pressure was chosen because the magmatic equilibration pressures, estimated from $\mathrm{Al}$ in hornblende barometry (Schmidt 1992) applied to our samples, was calculated to be $1-2$ kbar.

As expected, cumulates/restites are richer in $\mathrm{MgO}$, $\mathrm{FeO}_{\mathrm{T}}$, and $\mathrm{CaO}$ and lower in $\mathrm{Na}_{2} \mathrm{O}$ and $\mathrm{K}_{2} \mathrm{O}$ than the residual liquid (Figure 12). Given the simplicity of our calculations and our assumption of a very specific composition for a given plutonic system, there is a remarkable similarity between our calculated cumulates/restites and the Sierran mafic enclaves, corroborating previous suggestions that such enclaves are indeed of magmatic origin. $\mathrm{K}_{2} \mathrm{O}$, however, is an exception. $\mathrm{K}_{2} \mathrm{O}$ contents of Sierran mafic enclaves are much higher than the predicted cumulate/restite compositions. One possible explanation is that the $\mathrm{K}_{2} \mathrm{O}$ content of our starting composition is not high enough to stabilize biotite in the cumulate/restite; we note that the $\mathrm{K}_{2} \mathrm{O}$ content of our starting composition is lower than most of the Sierran mafic enclaves. However, it seems unlikely that any cumulates/restites with $\mathrm{K}_{2} \mathrm{O}$ contents $>3 \mathrm{wt} . \%$, as seen in the most K-rich Sierran mafic enclaves, could ever be generated by igneous processes unless an unusually K-rich system is involved.

In Figure 12, we have also plotted the dark metasedimentary enclaves for comparison. It can be seen that these dark metasedimentary enclaves deviate in terms of $\mathrm{CaO}$ and $\mathrm{K}_{2} \mathrm{O}$ and to a lesser extent $\mathrm{SiO}_{2}$. We note that although it does not seem possible to generate $\mathrm{K}$ rich cumulates/restites by crystallization of typical Sierran or PRB-type granitoids, it is possible from quartzofeldspathic metasediments. Thus, although some of the Sierran mafic enclaves may be explained as igneous 


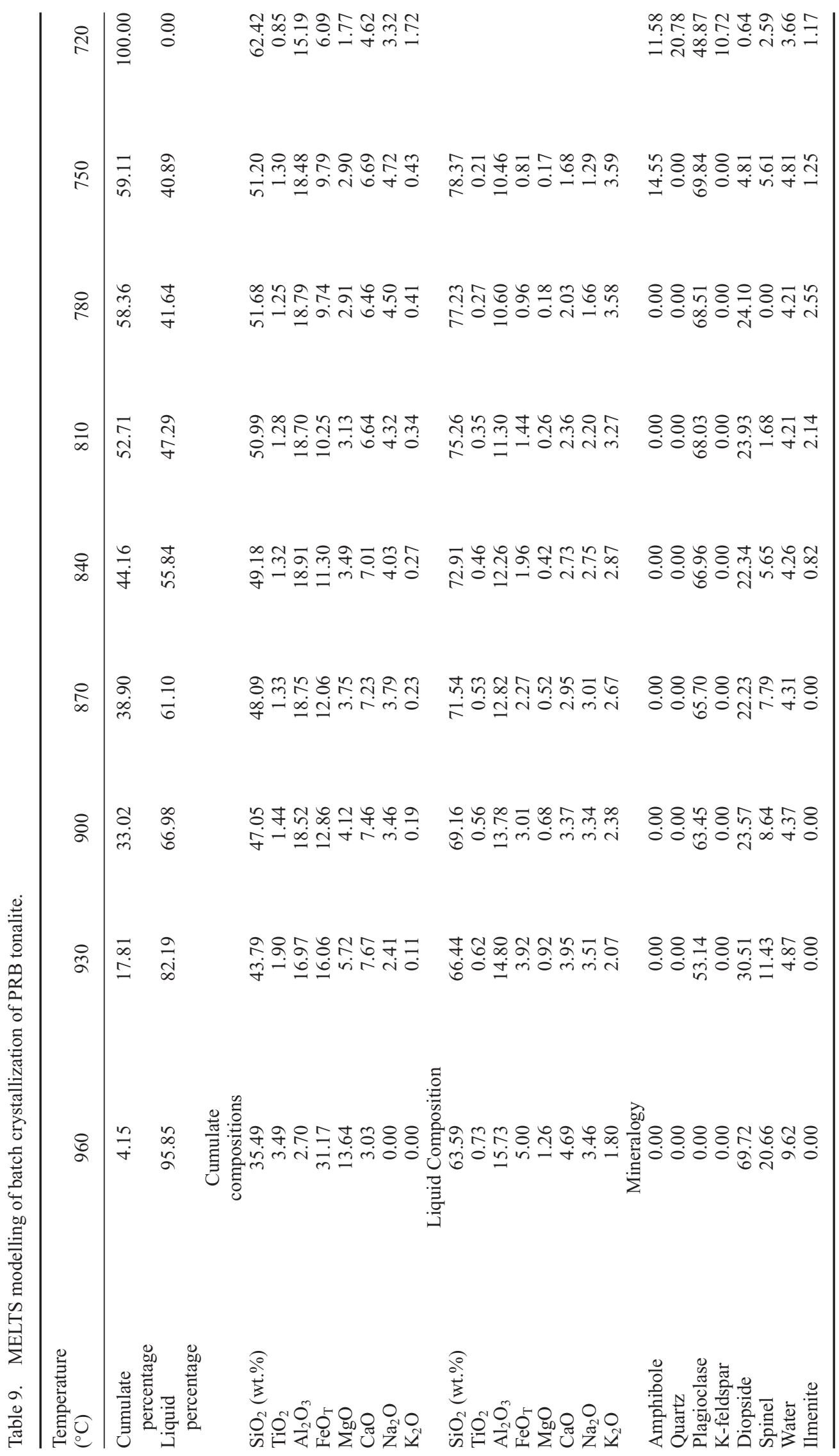



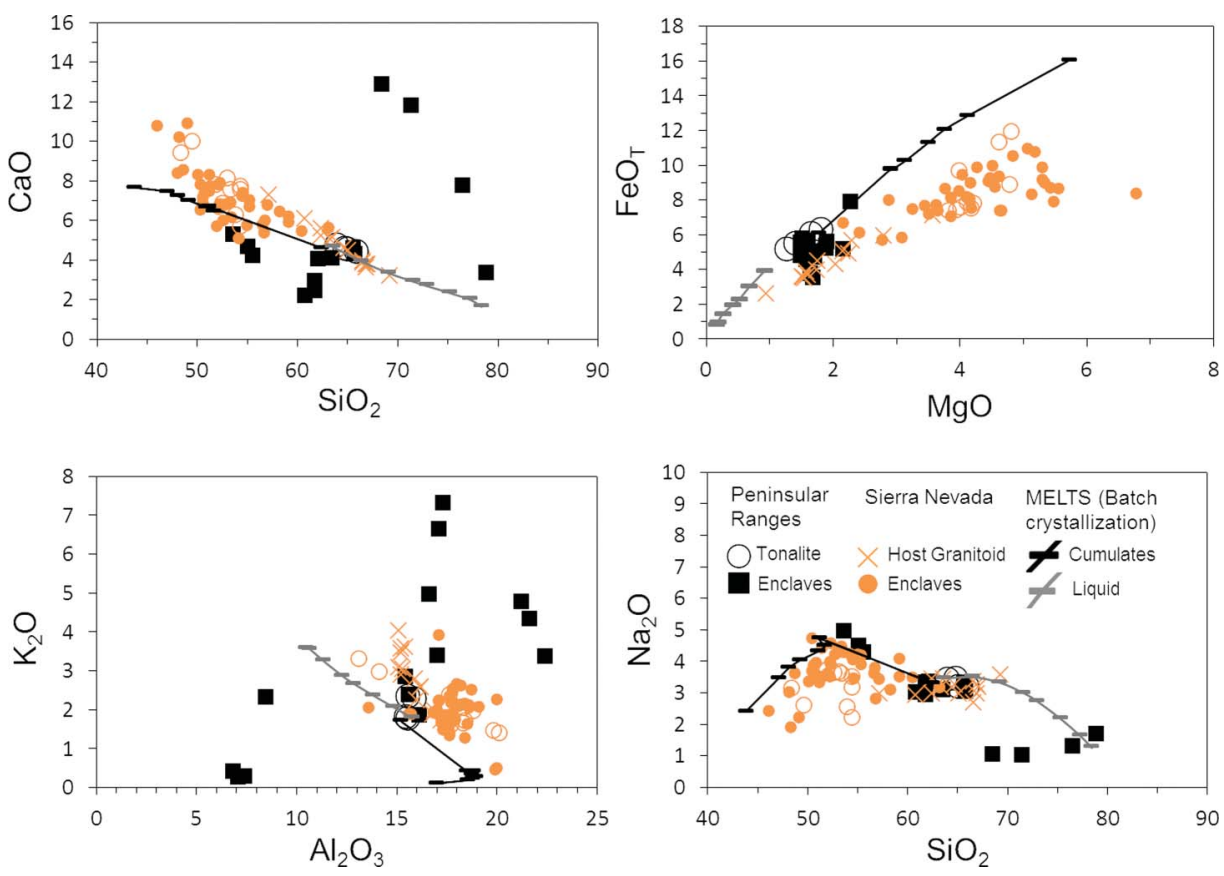

Figure 12. Major-element comparison of cumulates and metasedimentary enclaves. MELTS is used to model the composition of cumulates in equilibrium with liquid, using the Domenigoni Valley pluton host tonalite as the liquid's starting composition (see Table 8). Batch crystallization was simulated at a range of temperatures from $720^{\circ} \mathrm{C}$ to $960^{\circ} \mathrm{C}$. Pressure was kept at a constant pressure of $1 \mathrm{kbar}$. This is consistent with the 1-2 kbar calculated using the Al-in-hornblende barometry for the host tonalite from Domenigoni Valley. The compositions of cumulates are calculated mineral compositions and proportions for the given temperature range. Unlike modelled cumulates, PRB metasedimentary enclaves lack the linear continuity of major-element compositions from tonalite to enclaves.

cumulates/restites, a small fraction, such as the K-rich ones, might have a metasedimentary origin.

Alternatively, Sierran mafic enclaves may represent the liquid portion of a crystallizing pluton. Using MELTS, we calculated the composition of residual liquid formed by fractional crystallization of a continental arc basalt (parental arc basalt composition from Kelemen et al. 2003). Continuous fractional crystallization from $1200^{\circ} \mathrm{C}$ to $740^{\circ} \mathrm{C}$ was kept at a constant pressure of $1 \mathrm{kbar}$ to be consistent with MELTS calculations done in a batch crystallization model. In Figure 13, it is possible to see the overlap of major-element compositions of Sierran mafic enclaves with those of the modelled liquid compositions. Similarly, some metasedimentary dark enclaves show major-element overlap with MELTS liquid compositions, particularly in $\mathrm{FeO}_{\mathrm{T}}, \mathrm{MgO}, \mathrm{K}_{2} \mathrm{O}$, and $\mathrm{Al}_{2} \mathrm{O}_{3}$ concentrations.

In summary, we conclude that deviations from defined igneous arrays in terms of major-element systematics may be the best way to differentiate mafic enclaves of metasedimentary origin from those of true igneous origin. The more scattered major-element systematics of the metasedimentary enclaves are most certainly related to heterogeneity of their protoliths, and in the case of the Domenigoni Valley pluton, these enclaves have been arrested in various stages of chemical equilibration with the host magma, thereby preserving much of this heterogeneity. Had these enclaves resided longer in the magma chamber, allowing for further chemical equilibration, would the chemical systematics have approached those of the Sierran mafic enclaves, thereby masking the true extent of metasedimentary contribution to the formation of mafic enclaves?

\section{Conclusions}

Major and trace element characteristics provide us with the necessary diagnostic features to distinguish metasedimentary dark enclaves from igneous dark enclaves. We list the following criteria for distinguishing metasedimentary dark enclaves. (1) The major-element compositions of enclaves lack linear continuity with their granitoid host. Instead, mineralogy and major-element compositions are controlled by the protolith lithology. (2) With influx of $\mathrm{H}_{2} \mathrm{O}$, biotite can crystallize, provided the sedimentary protolith of an enclave is rich in K-feldspar, whereas amphibole can form from a carbonate-rich protolith. (3) Trace element abundances in metasedimentary dark enclaves typically vary significantly. Enclaves with carbonate-rich protoliths have lower REE abundances, whereas enclaves with quartzo-feldspathic protoliths have higher REE abundances. (4) The abundance 

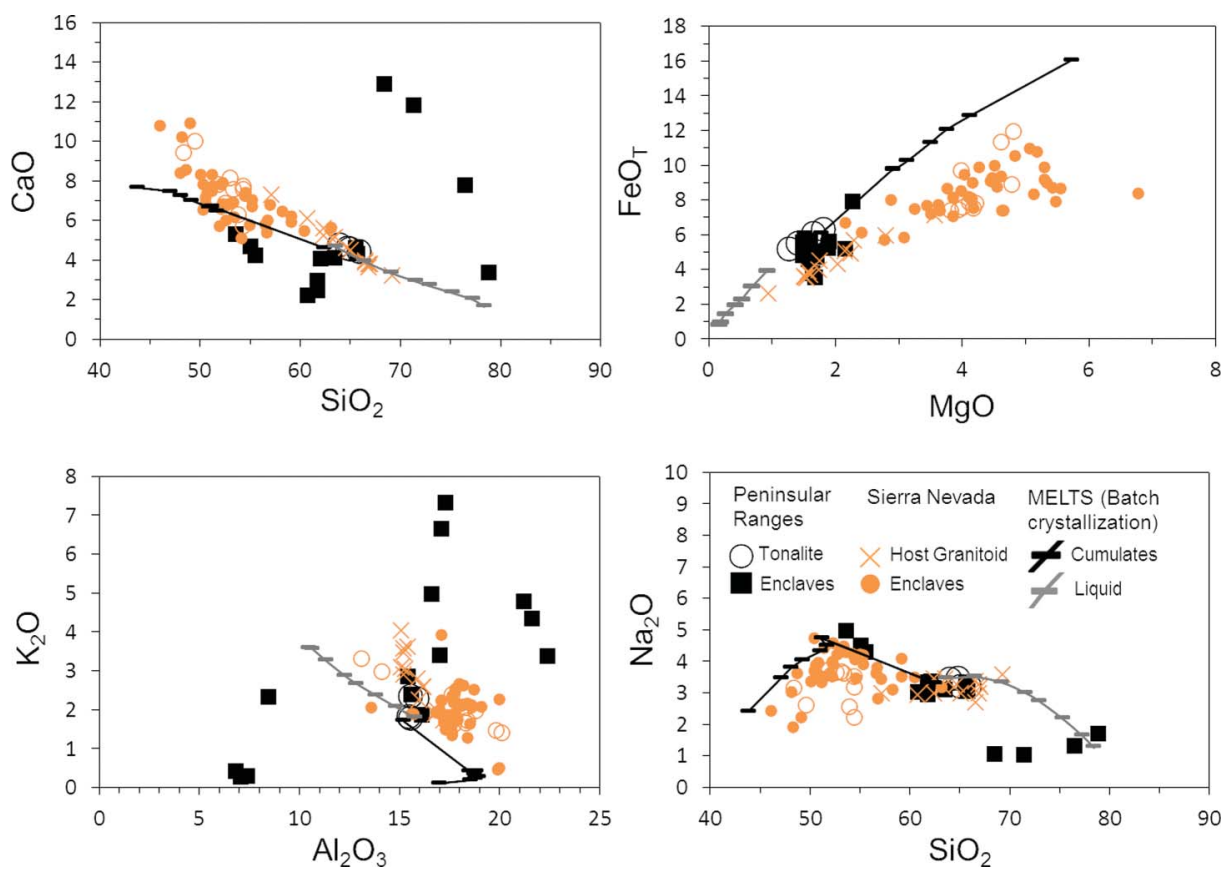

Figure 13. Major-element comparison of metasedimentary enclaves with the liquid residue of fractionally crystallized continental arc basalt. The starting composition of basalt comes from Kelemen et al. (2003). Continuous fractional crystallization from $1200^{\circ} \mathrm{C}$ to $740^{\circ} \mathrm{C}$ was kept at a constant pressure of 1 kbar.

of trace elements in a mafic mineral is dependent on the modal proportion of that mineral in enclaves.

As demonstrated, the compositional and physical similarities between igneous and metasedimentary dark enclaves may not be limited simply to mafic magmas, cumulates, or hybrid magmas. Because some dark metasedimentary enclaves may have been falsely identified as igneous enclaves, such may be worth revisiting. Dark enclaves lacking outcrop context of sediment metamorphism could be misidentified as being either basaltic or cumulate in origin. Therefore, this comprehensive look at dark enclaves with metasedimentary protoliths may provide a tool for diagnosing enclave origins, the implications of which can have profound effects on understanding what kind of differentiation path a granitoid body has followed.

\section{Acknowledgement}

This study was funded partly by the US National Science Foundation (NSF-EAR 1119315).

\section{References}

Allen, C.M., 1991, Local equilibrium of mafic enclaves and granitoids of the Turtle pluton, southeast California: Mineral, chemical, and isotopic evidence: American Mineralogist, v. 76, p. 574-588.

Bacon, C., 1986, Magmatic inclusions in silicic and intermediate volcanic rocks: Journal of Geophysical Research, v. 91, p. 6091-6112.
Barbarin, B., 1990, Plagioclase xenocrysts and mafic magmatic enclaves in some granitoids of the Sierra Nevada Batholith, California: Journal of Geophysical Research, v. 95, p. $17747-17756$.

Barbarin, B., 2004, Mafic magmatic enclaves and mafic rocks associated with some granitoids of the Sierra Nevada Batholith, California: Lithos, v. 80, p. 155-177.

Barbarin, B., Dodge, F.C.W., Kistler, R.W., and Bateman, P.C., 1989. Mafic inclusions, aggregates, and dikes in granitoid rocks, Central Sierra Nevada Batholith, California- Analytic Data: US Geological Survey Bulletin; 1899.

Blundy, J., and Sparks, R.S.J., 1992, Petrogenesis of mafic inclusions in granitoids of Adamello Massif, Italy: Journal of Petrology, v. 33, p. 1039-1104.

Brown, P.E., and Essene, E.J., 1985, Activity variations attending tungsten skarn formation, Pine Creek, California: Contributions to Mineralogy and Petrology, v. 89, p. 358-369.

Chappell, B.W., 1995, Magma mixing and the production of compositional variation within granite suites: Evidence from the granites of southeastern Australia: Journal of Petrology, v. 37, p. 449-470.

Chen, Y.D., Price, R.C., and White, A.J.R., 1989, Inclusions in three S-type granites from SE Australia: Journal of Petrology, v. 30, p. 1181-1218.

Chen, Y.D., and Williams, I.S., 1990, Zircon Inheritance in mafic inclusions form Bega Batholith Granites, Southeastern Australia: An ion microprobe study: Journal of Geophysical Research, v. 95, p. 17787-17796.

Condie, K.C., 1993, Chemical composition and evolution of the upper continental crust: Contrasting results from surface samples and shales: Chemical Geology, v. 104, p. 1-37.

DePaolo, D.J., 1980, Trace element and isotopic effects of combined wallrock assimilation and fractional crystallization: Earth and Planetary Science, v. 53, p. 189-202. 
Didier, J., 1973, Granites and their enclaves: The bearing of enclaves on the origin of granites: Amsterdam, Elsevier, $393 \mathrm{p}$.

Dodge, F.C.W., and Kistler, R.W., 1990, Some additional observations on inclusions in the granitic rocks of the Sierra Nevada: Journal of Geophysical Research, v. 95, p. 17841-17848.

Donaire, T., Pascual, E., Pin, C., and Duthou, J.-L., 2005, Microgranular enclaves as evidence of rapid cooling in granitoid rocks: The case of the Los Pedroches granodiorite, Iberian Massif, Spain: Contributions to Mineralogy and Petrology, v. 149, p. 247-265.

Dorais, M., Whitney, J., and Roden, M., 1990, Origin of mafic enclaves in the Dinkey Creek Pluton, Central Sierra Nevada Batholith, California: Journal of Petrology, v. 31, p. 853-881.

Dyer, B., Lee, C.-T.A., Leeman, W.P., and Tice, M., 2011, Open-system behavior during pluton-wall-rock interaction as constrained from a study of endoskarns in the Sierra Nevada Batholith, California: Journal of Petrology, v. 52, p. 1987-2008.

Eichelberger, J.C., 1975, Origin of andesite and dacite: Evidence of mixing at Glass Mountain in California and at other circum-Pacific volcanoes: Bulletin of the Geological Society of America, v. 86, p. 1381-1391.

Frost, T., and Mahood, G., 1987, Field, chemical, and physical constraints on mafic-felsic magma interaction in the Lamark Granodiorite, Sierra Nevada, California: Geological Society of America Bulletin, v. 99, p. 272-291.

Garrity, C.P., and Soller, D.R., 2009, Database of the Geologic Map of North America; adapted from the map by J.C. Redd, Jr. and others (2005): U.S. Geological Survey Data Series 424: http://pubs.usgs.gov/ds/424/ (accessed August 2011).

Gastil, R.G., 1975, Plutonic zones in the Peninsular Ranges of southern California and northern Baja California: Geology, v. 3, p. 361-363.

Ghiorso, M., and Sack, R., 1995, Chemical and mass transfer processes. IV. A revised and internally consistent thermodynamic model for the interpolation and extrapolation of liquid-solid equilibria in magmatic systems at elevated temperatures and pressures: Contributions to Mineralogy and Petrology, v. 119, p. 197-212.

Glazner, A., Bartley, J., Coleman, D., Gray, W., and Taylor, R., 2004, Are plutons assembled over millions of years by amalgamation from small magma chambers?: Geological Society of America Today, v. 14, p. 4-11.

Gromet, L.P., and Silver, L.T., 1987, REE variations across the Peninsular Ranges Batholith: Implications for Batholithic petrogenesis and crustal growth in magmatic arcs: Journal of Petrology, v. 28, p. 925-939.

Helgeson, H., Brown, T., and Leeper, R., 1969, Handbook of theoretical activity diagrams depicting chemical equilibria in geologic systems involving an aqueous phase at one atm and 0 to $300^{\circ} \mathrm{C}$ : San Francisco, Freeman Cooper and Co.

Hibbard, M.J., 1995, Petrography to petrogenesis: New York, Macmillan.

Johnston, A.D., and Wyllie, P.J., 1988, Interaction of granitic and basic magmas: Experimental observations on contamination processes at $10 \mathrm{kbar}$ with $\mathrm{H}_{2} \mathrm{O}$ : Contributions to Mineralogy and Petrology, v. 98, p. 352-362.

Kelemen, P.B., Hanghoi, K., and Greene, A.R., 2003, One view of the geochemistry of subduction-related magmatic arcs, with an emphasis on primitive andesite and lower crust: Treastise on geochemistry, v. 3, p. 593-659.

Kistler, R.W., Wooden, J.L., and Morton, D.M., 2003, Isotopes and ages in the northern Peninsular Ranges batholith, southern California: U.S. Geological Survey Open-File Report 03-489. p. 45.

Kumar, S., and Rino, V., 2006, Mineralogy and geochemistry of microgranular enclaves in Palaeoproterozoic Malanjkhand granitoids, central India: Evidence of magma mixing, mingling, and chemical equilibration: Contributions to Mineralogy and Petrology. v. 152, p. 591-609.

Lee, C.-T.A., Morton, D.M., Kistler, R.W., and Baird, A.K., 2007, Petrology and tectonics of Phanerozoic continent formation: From island arcs to accretion and continental arc magmatism: Earth and Planetary Science Letters, v. 263, p. 370-387.

Lee, C.-T.A., Shen, B., Slotnick, B.S., Liao, K., Dickens, G.R., Yokoyama, Y., Lenardic, A., Dasgupta, R., Jellinek, M., Lackey, J.S., Schneider, T., and Tice, M., 2012, Continental arc-island arc fluctuations, growth of crustal carbonates and long-term climate change: Geosphere, v. 9. doi: 10.1130/GES00822.1.

Maas, R., Nicholls, I.A., and Legg, C., 1997, Igneous and metamorphic enclaves in the S-type Deddick Granodiorite, Lachlan Fold Belt, SE Australia: Petrographic, geochemical and $\mathrm{Nd}-\mathrm{Sr}$ isotopic evidence for crustal melting and magma mixing: Journal of Petrology, v. 38, p. 815-841.

Morton, D.M., 1999, Preliminary digital geologic map of the Romoland quadrangle, Southern California: US Geological Survey.

Orsini, J.B., Cocirta, C., and Zorpi, M.J., 1991, Genesis of mafic microgranular enclaves through differentiation of basic magmas, mingling, and chemical exchange with their host granitoid magmas, in Didier, J., and Barbarin, B., eds., Enclaves and granite petrology: New York, Elsevier, p. 625.

Phillips, G.N., Wall, V.J., and Clemens, J.D., 1981, Petrology of the Strathbogie batholith: A cordierite-bearing granite: Canadian Mineralogist, v. 19, p. 47-64.

Poli, G., and Tommasini, S., 1991, Model for the origin and significance of microgranular enclaves in calc-alkaline granitoids: Journal of Petrology, v. 32, p. 657-666.

Price, R.C., 1983, Geochemistry of a peraluminous granitoid suite from NE Victoria, SE Australia: Geochemica et Cosmochimica Acta, v. 47, p. 31-42.

Reid, J.B., and Hamilton, M.A., 1987, Origin of Sierra Nevadan granite: Evidence from small scale composite dikes: Contributions to Mineralogy and Petrology, v. 96, p. $441-454$

Rudnick, R., and Fountain, D., 1995, Nature and composition of the continental crust: A lower crustal persepective: Reviews of Geophysics, v. 33, p. 267-309.

Ryerson, F.J., and Hess, P.C., 1978, Implications of liquidliquid distribution coefficients to mineral-liquid partitioning: Geochimica et Cosmochimica Acta, v. 42, no. 6, p. 921-932. doi: 10.1016/0016-7037(78)90103-5.

Schmidt, M.W., 1992, Amphibole composition in tonalite as a function of pressure: An experimental calibration of the Alin-hornblende barometre: Contributions to Mineralogy and Petrology, v. 110, p. 304-310.

Taylor, S.R., McLennan, S.M., Armstrong, R.L., and Tarney, J., 1981, The composition and evolution of the continental crust: Rare earth element evidence from sedimentary rocks: Philosophical Transactions of the Royal Society of London, v. 301, p. 381-399.

Tepper, J.H., and Kuehner, S.M., 2004, Geochemistry of mafic enclaves and host granitoids from the Chilliwack Batholith, Washington: Chemical exchange processes between coexisting mafic and felsic magmas and implications for the interpretation of enclave chemical traits: The Journal of Geology, v. 112, p. 349-367. 
Tobisch, O., McNulty, B., and Vernon, R., 1997, Microgranitoid enclave swarms in granitic plutons, central Sierra Nevada, California: Lithos, v. 40, p. 321-339.

Todd, V.R., Erskine, B.G., and Morton, D.M., 1988, Metamorphic and tectonic evolution of the northern Peninsular Ranges Batholith, southern California, in Ernst, W.G., ed., Metamorphism and crustal evolution of the western United States: Englewood Cliffs, Prentice Hall, p. 894-937.

van Marcke de Lummen, G., and Verkaeren, J., 1986, Physicochemical study of skarn formation in pelitic rock, Costabonne peak area, eastern Pyrenees, France: Contributions to Mineralogy and Petrology, v. 93, p. 77-88.

Vernon, R.H., 1990, Crystallization and hybridism in microgranitoid enclave magmas: Microstructural evidence: Journal of Geophysical Research, v. 95, p. 17849-17859.
Wetmore, P.H., Herzig, C., Alsleben, H., Sutherland, M., Schmidt, K.L., Schultz, P.W., and Patterson, S.R., 2003, Mesozoic tectonic evolution of the Peninsular Ranges southern and Baja California, in Johnson, S.E., Paterson, S.R., Fletcher, J.M., Girty, G.H., Kimbrough, D.L., and Martin-Barajas, A., eds., Tectonic evolution of northwestern Mexico and the southwestern USA: Geological Society of America, p. 93-116.

White, A.J.R., and Chappell, B.W., 1977, Ultrametamorphism and granitoid genesis: Tectonophysics, v. 43, p. 7-22.

Wiebe, R.A., Smith, D., Sturm, M., King, E.M., and Seckler, M.S., 1997, Enclaves in the Cadillac Mountain Granite (Coastal Maine): Samples of hybrid magma from the base of the chamber: Journal of Petrology, v. 38, p. 393-423. 